\title{
DIE BETEKENIS VAN DIE BEGRIP „VREES-VAN-DIE-HERE” IN SPREUKE, JOB EN PREDIKER
}

\author{
Biblografiese OpMerkings.
}

\begin{abstract}
Onderstaande artikel is 'n gedeeltelike samevatting en verwerking van 'n werkstuk wat ons onder Prof. GEMSER in 1946 verrig het aan die Universiteit van Pretoria. Sedertdien het daar weer twee bydraes oor hierdie onderwerp verskyn nl. H. A. Brongers, La Crainte du Seigneur, in: Oud-Testamentische Studiën, uitgegeven door P. A. H. de Boer, Dl.V, 1948, bls. 15 lv.v., en B. J. Oosterhoff, De V reze des Heren in het Oude Testament, Utrecht, 1949, 'n doktorsgraad-dissertasie aan die Ryksuniversiteit te Utrecht. Ongelukkig gee ook geen van hierdie twee ondersoekers 'n eksplisiete ,geskiedenis-van-die-begrip" nie. Die opmerking van LoRENTZ DürR Das Erziehungswesen im Alten Testament und im Antiken Orient, Leipzig, 1923, p. 124,noot, dat die geskiedenis van hierdie begrip nog geskryf moet word, is dus vandag ook nog waar.

Ons kan nog op die volgende literatuur i.v.m. ons onderwerp opmerksaam makk: A. W. EIchrodt, Theologie des A.T.-s, Leipzig 1939, Bd. III, p. 18vv.; Johannes Hempel, Gott und Mensch in A.T., Stuttgart 1936, p. 32-33; Aug. Klostermann, Gottesfurcht als Hauptstück der Weisheit, 1885; Ludwig KöHler, Theologie des A.T.-s, Tübingen 1936, p. 37v.v.; JoH. PeDersen, Istael III and IV, Kopenhagen 1934, p. 201v.v.; TH. PAfFrath, Gott, Herr und Vater, Paderborn 1930, p. 258v.v.; H. SEEGER, Triebkraften des religiösen Lebens in Israel und Ba.
\end{abstract} bylonien, Tübingen 1934 .

B. Tydskrifte: B. Bamberger, Fear and Love of God, HUCA 1929, p. 39v.v.; B. Gemser, Jir'at Jahwè i.d. Psalmen, Nieuwe Theol. Studiën, Mei-Junie 1939; N. Grück, Das Wort hesed in a.t, Sprachgebrauche, ZAWB 47, 1927; W. F. LoFrHOUSE, Hen and Hesed in the O.T., ZAW 51, 1933 p. 29v.v.

C. Die Verhouding v.d. Motiewe „Vrees en Heiligheid": J. HÄNEL, Religion der Heiligkeit, Gütersloh 1931; S. KIERKEGAARD, Furcht und Zittern, Jena 1909 en Der Begriff der Angst, Jena 1912; Rudolph Otro, Das Heilige, 15A., Gotha 1926; G. vAN DER LeEUw, Phänomenologie der Religion, Tübingen 1933.

D. Kommentare: I. S p r e u ke: B. Gemser in Serie Handbuch zum A.T. (Gemser, Sprüche), en in Serie Text en Uitleg (Gemser., T.U.) en C. H. Toy in Setie I.C.C. II. Jo b : A. H. K. Bleeker in Serie Text en Uitleg (Bleeker, T.U.) en Druver and Gray, Serie I.C.C. III. P r e d i k e r : Franz Delitsch,; Barton, I.C.C., Gemser, T.U.II. en H. W. Hertzberg in Komm. z.A.T. v. E. Sellin.

E. Algemene Literatuur hier aangehaal: L. DüRR, Ursprung und Aufbau der Aufbau der ist. jüd. Heilandserwartung, Berlin 1925 (DürR, Aufbau); K. FAHLGREN, Sedaqa, nahestehende und entgegengesetzte Begriffe in A.T.., 1932; RUDOLPH Kirtel, Die Religion des Volkes Israel, '.A., Leipzig 1933; H. MEINHoldt, Die Weisheit Istaels in Spruch, Sage und Dichtung, Leipzig, 1908; ERNST SELLIN, Einleitung i.d. A.T., 7.A., Leipzig 1935 (SELuN, Einleitung). Das A.T. auf religionsgeschichtlicher Grundlage, 1. Teil, Leipsiz, 1933.; P. Volz, Prophetengestalten des A.T.-s., Stuttgart 1938.; DR. TH. C. VRIEzEN, Hoofdlijnen der Theologie a an het Oude Testament, Wageningen 1949.

Hierdie bibliografiese opmerking gee 'n oorsig oor die vernaamste literatuur rondom die begrip V rees-van-die-Here in die Wysheidsliterat $u$ u r van die O.T., en ons kan daardeur ook in die verkorte vorm aanhaal uit bostaande werke.

\section{INLeidende Gedeelte}

Teologie is sinvolle s preke. Dit is sinvolle spreke va nu it Gods Woord tot die mens. Dit is geen teoretiese kennis nie, maar dit moet trag om "wysheid" te wees. Dit is geen spreke in die oneintlike sin van "gepraat" (Duits: „Gerede”) nie, maar dit is 'n prakties-eksistensiële $1 \mathrm{e}$ w e $\mathrm{n} \mathrm{s}$ vor $\mathrm{m}$ wat beide die spreker én die toehoorder in die ligkring van die waarheid betrek. Wie die teologie sien as byna-nuttelose 
akademies-teoretiese kennis, en dit teenoor die „volle” praktyk stel, het die teologie van haar eintlike karakter van spreke-as-lewens-vormin-diens-van-God ontdoen. Juis hierdie uitspraak (dat teologie teoretiese spreke is met weining praktiese betekenis) is teoretiese kennis en is slegte, oneintlike teologie.

Ook ons ondersoek na die betekenis van die Vrees-van-die-Here trag om teologie te wees. Dit wil uit-die-s a a k-s elf (soos dit te vinde is in die geskrewe vorm van Gods Woord, in die Heilige Skrif) die sin en betekenis van die term bepaal, en dit dan i.v.m. ons eie lewe, ons eie lewens- en wêreldbeskouing, en i.v.m. die lewens- en wêreldbeskouing van die wêreld waarin ons leef, bring.

Ons werkwyse is hier dus as volg: Ons gaan na waar die term ,,vreesvan-die-Here" voorkom in die genoemde Bybelboeke. By elke plek waar dit voorkom, probeer ons insien en be-gryp wat die eintlike, logiesgrammatikale sinsgehalte en betekenis van die term is, in dié sinvolle verband waat dit voorkom. As ons verskeie plekke so nagegaan het, vind ons miskien verskillende betekeniskleure van die term. Dan bring ons die één betekenisskakering i.v.m. 'n ander betekenisskakering, en so probeer ons om ' $n$ sinvolle samehang in te sien. Sodoende verhelder ons die samehang, die ,vrees-van-die-Here" uit die saak self d.w.s. uit die Heilige Skrif, die Heilige Skrif ook in sy vorm van 'n ,,vreemde taal" wat onstaan het u i t, en gegroei het i n 'n ,,antieke" kultuursfeer.

Die Heilige Skrif is ' $n$ besondere vorm van spreke nl. spreke as geskrewe woord, as boek, as dié Boek. Dit het in ons verband veral twee aspekte wat belangrik is, nl. (i) Die Bybel was nie één dag klaargeskryf nie, maar het in die loop van eeue ontstaan. Moses het bv. lank voor Jesaja gespreek en sy woorde op laat skryf. So is die boek Spreuke as 'n geheel ook veel ouer as die boek Prediker. (ii) Maar nou is spreke altyd spreke van 'n bepaalde situasie af uit, bv. iemand wat in nood verkeer spreek anders en op 'n ander wyse as een wat rustig gesels. Maar ook die mense wat vroeër geleef het, spreek op 'n ander wyse en 'n woord beteken vir hulle iets anders as vir ons wat daarná leef. Ons kan alleen 'n woord (gesproke of geskrewe) vanuit sy situasie, uit sy ,,agtergrond" uit, reg verstaan. Anders gesê: Die betekenis van 'n woord en sinvolle woordegroep is deur die agtergrond waarin en waaruit dit gespreek word, bepaal. Maar nou is die agtergrond waaruit die boek Spreuke ontstaan het en waarin dit sy sinvolheid het, anders as die agtergrond van die boek Prediker. Miskien het die term „Vrees-van-die-Here” ook 'n ander betekenis-skakering in die boek Spreuke as in die boek Prediker; en as ons die betekeniskleure van dieselfde begrip i.v.m. die agtergrond (geskiedenis, kultuurgeskiedenis en spreeksituasie) bring, dan verstaan ons die betekenis daarvan ook miskien beter. Dit bedoel ons as ons sê dat ons die ,geskiedenis-van-die-begrip" bepaal. Om hierdie taak uit te voer is dit nodig dat ons die betrokke boeke in hulle onderdele en gehele noukeurig rangskik na hulle ouderdom, na hulle tydsorde. 


\section{Die Rangskikking van die Drie Bybelboeke na Histories-Kritiese MaAtstaf.}

\section{A. Spreuke.}

SelliN ${ }^{1}$ ) klassifiseer die boek Spreuke op grond van verskillende opskrifte bo-aan elke versameling-van-spreuke in $\mathrm{v}$ y $\mathrm{f}$ onderafdelings:

(1) Hoofst. 1-9 wat blykbaar uit die 4de eeu v.C. stam: Sellin verwys na $S p r .2^{16 \mathrm{v}}, 5^{3 \mathrm{v}} \cdot, 6^{24 \mathrm{v}}, 7^{5 \mathrm{vv}},{ }^{16}, 8^{22 \mathrm{v}}$. en $9^{33 \mathrm{vv}}$. as bewysplekke vir hierdie datering.

(2) Hoofst. $10^{1}-22^{16}$ wat 'n hele aantal koningsspreuke uit die voorexiliese tyd bevat én

(3) Hoofst. $22^{17}-24^{34}$ wat miskien deur Josia in die jaar 622 v.C. versamel is, stam albei heelwaarskynlik uit Salomo se regeringstyd tot en met die ondergang van die Ryk.

(4) Hoofst. 25-29 wat waarskynlik deur koning Hiskia versamel is, en die oudste spreuke bevat, stam uit die tyd tot aan Salomo se regering.

(5) Hoofst. 30-31 is later spreuke, maar die presiese datering is moeilik.

MEINHOLDT ${ }^{2}$ ) het dieselfde indelingsskema en absolute datering as Sellin, behalwe dat hy afdeling 3 as jonger spreuke beskou en nie met afdeling 2 saamgroepeer nie. Sy indeling is dus soos volg: Indelingsgroepe 2 en 4 is ouer spreuke terwyl die afdelings 1,3 en 5 jonger spreukegroepe is. RUD. KITTEL ${ }^{3}$ ) wyk weer af van bostaande dateringsskemas en meen dat hoofst. 1-9 uit 323 v.C. en volgende jare stam, dat hoofst. 10-13 in \pm 400 v.C. ontstaan het. Die ander spreuke is uit 'n later tyd. Gemser ${ }^{4}$ ) het in ooreenkoms met Seldin en Meinholdt egter Kittel weerlê deur 'n goedbegronde en presiese dateringsskema op te stel. GEMSER wys daarop dat volgens die M.T. nie 5 nie, maar eintlik 9 onderafdelings van spreukeversamelinge onder die huidige titel verenig is, nl. I Hoofst. $1^{1 v v}$. Inleiding gedeelte, II Hoofst. 101vv. Eerste Hoofdecl, III Hoofst. $22^{17 v v .}$ Eerste aanhang, IV Hoofst. $24^{23 v v}$. Tweede aanhang, V Hoofst. $25^{1 \mathrm{vv} .}$ Tweede Hoofdeel, en die kleinere versamelinge V'I Hoofst. $30^{1 \mathbf{v} v}$, VII Hoofst. $30^{15 v v}$, VIII Hoofst. $31^{1 v v}$, IX Hoofst. $31^{19 v v}$. Behalwe die verskillende opskrifte, vorm en inhoud (bv. doeblette), is ook die feit dat die LXX 'n ander volgorde naamlik I, II, III, VI, IV, VII, VIII, V en IX het, ' $n$ aanduiding dat die indeling in 9 onderafdelings 'n noukeurige skema is. In T.U. dateer Gemser soos volg: II stam uit ongeveer 'n anderhalfeeu ná Salomo, V uit die tyd van Hiskia, III uit die 7 de eeu v.C. en IV ontstaan in die volgende 3 eeue. In Sprüche gee hy op grond van vorm, inhoud, formele analogie van Spreuke met Egiptiese spreuke ens., die volgende datering: Afdelings II en $\mathrm{V}$ is die oudste versamelings.

\footnotetext{
1) Einleitung, p. 134-138.

2) Meinhold, t.a.p.

2) Rud. KitTel, t.a.p.

4) Gemser, T.U., p. $21 \mathrm{v}$. en Sprüche, p. 3v.
} 
Op grond van meerdere vermaningswoorde ten koste van uitsprake in Afd. V, skyn Afd. II tog die oudste te wees. Afd. II stam skynbaar uit die tyd 50 jaar ná Salomo terwyl afdeling $\mathrm{V}$ in Hiskia se tyd versamel is. Aan afd. II is die aanhangsel III en IV gevoeg. Afd. III staan in noue verband met die Spreukeboek van Amen-em-ope d.i. of in die 22ste dinastie (945-745 v.C.) óf in die 26ste dinastie (633-525 v.C.). Die presiese data van die kleiner versamelinge IV en VI-IX is onbepaalbaar, maar hulle is tog jonger versamellinge as II, V en III. In afd. VII is baie ou materiaal opgeneem. Afd I is na-eksilies ${ }^{5}$ ) en is die jongste versameling.

\section{B. Die Boek Job.}

Die boek Job se onstaanstyd word deur Sellin ${ }^{6}$ ) weens die internasionale, en bygevolg vae maatstawwe, tussen 600 en 300 v.C. gestel. Hy meen dat die Elihu-redevoering (Hoofst. 32-37), van jonger datum is, terwyl Hoofst. 28 ook nie oorspronklik is nie. In sy Isr.-jüd Rel.gesch. stel Sellin die ontstaansdatum van die boek Job spesifiek as in die 4de eeu v.C. MeinholdT ${ }^{7}$ ) stel Job se ontstaanstyd in die 5de eeu v.C. Sy bewysgronde is taal- en stylaard maar ook inhoud, nl. die in $\mathrm{d} i \mathrm{v}$ id u teenoor God. BlekKER ${ }^{8}$ ) sê i.v.m. die datering van Job die volgende: Die in $\mathrm{druk}$ as sou Job 'n ryk herdervors uit die patriargetyd wees, is geen maatstaf vir datering nie. Die vraag waarmee Job worstel en sy waarskynlike ooreenkoms met Jeremia ${ }^{9}$ ) die enkele Arameismes, ja, die hele gedagteinhoud wat ooreenkom met later Psalms, wys op 'n tydperk ná die ballingskap, waarskynlik op die 5 de eeu v.C. Job moes dus net ná Spreuke 1-9 geskryf gewees het $^{10}$.)

\section{Die Boek Prediker.}

Die ontstaanstyd van die boek Prediker word deur Sellin ${ }^{11}$ ) gestel tussen 300 en 200 v.C. Hy meen dat Sirah, in 200 v.C. die boek as geheel voltooi gevind het. In sy Isr.jüd. Relgesch. stel hy bygevolg die ontstaansdatum net vóór 200 v.C. Meinhold stel op grond van Graecismes (Epikurisme, Skeptisisme ens. - wat ons betwyfel), en op die grond van taal en styl die ontstaansdatum in die 2 de helfte van die derde eeu v.C. Samevattend kan ons dus met Gemser ${ }^{12}$ ) sê dat: „Het oudste wijsheidsboek uit Israel is, zoowel wat vorm als inhoud aangaat, de verzameling Spreuken van Salomo." Volgens hom is Job die hoogtepunt van Israellie-

\footnotetext{
5) Gemser, Sprüche, p. $5 \$ 4$.

6) Einleitung, p. $138 \mathrm{v}$.

7) Meinholdt, t.a.p.

8) BLEEKER, T.U., p. 7.

1) Jer. $12^{1}, 20^{14-18}$ - hoewel Job tog jonger is.

10) vgl. ook Gemser, T.U., p. 17.

11) Einleitung, p. $148 v$.

12) GEMSER, T.U., p. 17.

13) Gemser, T.U.II, p. 62-63.
} 
tiese spreukdigting, en op grond daarvan dat Job 'n protes is teen een van die vernaamste grondstellinge van die oorgelewerde wysheid (nl. die geloof van die onfeilbaar sig op aarde, uitwerkende Goddelike geregtigheid en vergelding), is Job jonger as Spreuke.

Weens die polemiese houding teen die ,Wysheid" en die spore van buitelandse filosofie, is die boek Prediker ook jonger as die vreugdevolle Spreukeboek uit die bloeityd van Israel se geesteslewe. Prediker is ná Job geskryf. Deur taaleienaardighede, weerspieëlde politieke toestande, Graecismes, die gedagteverband met die Sadduseïsme (nl. deisme), stam Prediker heelwaarskynlik uit die 2 de helfte of laaste kwart van die 3 de eeu v.C.

S a m e vat t ing: Op grond van verskillende verhoudinge met ander dateerbare stof, op grond van verskillende vorme, styl en taaleienaardighede en weerspiëelde toestande, en op grond van inhoudelike uitsprake m.a.w. uit die saak self, deel die materiaal wat ons ondersoek, sig in die volgende tydskema in, en laat dit sig as volg dateer: $\mathrm{S} \mathrm{p} \mathrm{r} \mathrm{e} \mathrm{u} \mathrm{k} \mathrm{e}$ 10-2217 ontstaan na \pm 50 jaar ná Salomo, Spr. 25-29 is ook oud en in Hiskia se tyd ( \pm 700 v.C.) versamel, Spr. $22^{17}-24$ stam miskien uit die 7 de eeu, terwyl Spr. $30^{15 v v}$. ou materiaal bevat maar saam met Spr. $24^{23 \mathrm{vv}}$. $30^{1},{ }^{14} \mathrm{en}, 31^{1 \mathrm{v}}$ jonger is as die vorige versamelinge. Spr. 1-9 ná-eksilies en is die jongste versameling in die Spreukeboek. J o b is net ná Spr. 1-9 geskryf, waarskynlik in die 5de eeu v.C. en P r e d i k e r in die laaste helfte van die 3 de eeu v.C.

Laat ons nou, ná die noodsaaklike historiese omordening van ons materiaaal, uit die materiaal self uit, die samehang "Vrees-van-die-Here" helderder laat word in die eksegetiese ondersoek van die onderwerp.

III. Die Eksegetiese Ondersoek Na die Sin van die VRees-van-die-Here in Spreuke, Job en Prediker.

\section{A. Spreuke.}

(a) Hoofst. 10 $0^{1}-22^{16}$ (Eerste Hoofdeel).

Hierdie versameling is tipies van die ouere Israelitiese spreukdigting: Die groepering is los en slegs nou en dan "logies”, gewoonlik ,enkelspreuke" wat soms op grond van mnemotegniese klankooreenkoms saamgroepeer is. Tơ ${ }^{14}$ ) noem hierdie versameling "detatched aphorisms". Omdat die logiese volgorde ontbreek, asook die logiese parallelisme in die strofiek, is die wyere verstaanssamehang soms moeilik te begryp. Hierdie versameling stam miskien uit die praxis van die onderrig.

(1) $10^{27}$ : „Die Vrees-van-die-Here vermeerder die dae, maar die jare van die goddelose word verkort". Hierdie vers is ingeskakel in die

14) ToY, a.w., p. 197. 
min-of-meer logiese sinsamehang $10^{27,32}$, waar die lot van die regverdiges (=Jahwevresendes) en die lot van die goddeloses uitgebeeld word: Die Jahwevresende, die regverdige (wie se houding dié van „piety”, van „religion" is), sal die loon van 'n kwalitatief-lang lewe (d.i. tegelyk ook 'n rustige, ongestoorde lewe) ontvang.

(2) $13^{13}$ : „Wie die Woord verag, bly verpand daaraan, maar wie die gebod vrees, ontvang vergelding". (a) „Woord" (=miskien Tora) en ,gebod" word hier parallel en feitlik sinomiem gestel. (b) "Vrees" en „verag" word hier as direkte teëstellinge opgewys. „Verag” kan beteken koud-staan-teenoor, maar kan ook 'n meer aktief-polemiese sin hê. Dit is in die Wysheidsliteratuur v.d. O.T. die houding van die ,,spotter", die ,god-lose”, die ,dwaas”. ,Vrees” beteken hier: ag-gee-op. VAN DER LEEUW ${ }^{15}$ ) meen dat ag-gee-op (ohservance) en religio (vgl. Toy ${ }^{16}$ : Vrees = „piety” = „religion") één saak is.

Albei, die Jahwevresende (regverdige) én die goddelose (spoiter, dwaas) is betrek in die gevaarsone van Gods Woord, van Sy gebod. Albei sal h i e $\mathrm{r}$ hul loon ontvang ${ }^{17}$, maar die loon van dié wat Gods gebod ,vrees" is goed, en die ander s'n straf. Die mens wat hier d u r a $t$ i ef vrees (= ag-gee-op), hoef nie te vrees (= paniese skrik) vir die abrupte, skielike einde nie. Exodus $20^{20}$ gebruik dieselfde woord (jārē) vir beide die bang-wees (skrik-in-die-onverwagte-oomblik) én die duratiewe agsaamheid, onderhouding van die gebooie, religio. Die vrees as religio is ' $\mathrm{n}$ i $\mathrm{n}$ e $\mathrm{rli}$ k e houding, die oombliklike vrees kom deur magte van buite af.

(c) Die term vrees-vir-die-gebod is ook Babilonies nl. pālāhu zikru ${ }^{18}$.) Die „Vrees-vir-die-Here” en die vrees-vir-Sy-gebod word gelykgestel, omdat die gebod die kommunikasiewyse van God en die mens is. Volgens GEMSER ${ }^{19}$ ) is dit kenmerkend van hoofst. $10-22^{16}$ om die menslikeverhoudinge met die maat van Jahwe se wil (Sy afkeer en welgevalle) af te meet. So is dit bv. in $14^{2}$ en ${ }^{31}$ en $17^{5}$ waar ,Jahwe te vrees, te eer of te verag" die hoogste kriteria van sedelike beoordeling is. Jahwe besit die alleenregte maatstaf en beproef die harte. Jahwe se Gebod en Woord $\left(13^{13}, 19^{18}\right)$ geld met absolute autoriteit. Die hele lewe skyn hier aan God gebonde te wees $\left(18^{22}, 19^{3}, 20^{12}, 22^{14}\right)$ en word deur Hom afgeweeg en gemeet.

(d) EIchrodT $^{20}$ ) druk die verhoudingswyse van die samehang: Vrees-Gebod-Onderhouding van gebooie, as agting, as religio, as volg uit: Die werklik-v r e e s l i k e (verskriklike) God openbaar Sig in Sy verbond as 'n aan-orde-houdende Iemand en Beskutter. Hierdie orde is Sy w il wat te voorskyn tree en te vinde is in Sy gebod, in Sy woord. Die mens gee ag op hierdie gebod, onderhou dit. Die primêre $\mathrm{skrik}$ en a $\mathrm{ng}$

15) v. D. LeEuw, Phän, Engelse Vertaling p. 49-50.

16) ToY, a.w. p. 197.

17) vgl. Spr. $11^{31}$ en Rom. $2^{12}$ en $3^{\circ}$ en ${ }^{18}$.

18) GEMSER, N.T.S., p. 146.

19) Gemser, T.U., p. 63.

20) EichrodT, a.w., p. 18v.v. 
vir die numineuse tree terug agter die duratiewe vertroue $\mathrm{n}$ s ele. ment $^{21}$ ) $\mathrm{nl}$. die onderhouding van die gebooie wat altyd ,daar" is. Tog bly die skrikaanjagende element voor die Heilige Verbondsgod die waarborg vir hierdie vertroue. Hier het ons dus die dubbel-polarisme ${ }^{22}$ ) in die Jahwevrees. Dit is par exellence moontlik waar die e $\mathrm{n} \mathrm{ke} \mathrm{l}$ i $\mathrm{ng}$ voor God staan, soos dit die geval is in die Wysheidsliteratuur van die O.T. ${ }^{23}$.) V'rees-van-die-Here is een van die grondvorme van die verhouding van God en die en keling.

(e) Die verhouding: Kennis-Jahwevrees-Gebodsonderhouding-Wysheid (wat tipiese figure in die Wysheidsliteratuur is), lê sig aan ons by die ontleding van die begrip ,vrees-vir-die-gebod," as volg bloot: K e n n i s van-goed-en-kwaad kry ons deur die wet van $\mathrm{God}^{24}$.) Om die etiese norm wat só ingewin is, toe te pas (d.i. ag-gee-op-die-gebooie, die gebooie te onderhou) is J a h we v r e e s. Dit lei weer tot 'n goeie, rustige lewe, tot lewenskuns. Dié lewenskuns word wysheid genoem.

Opsommend kan ons die hoofinhoud van hierdie vers met Toy ${ }^{25}$ ) as rolg stel: "Safety lies in obedience".

(3) $14^{2}:$,Wie in opregtheid wandel, vrees die Here; maar hy wat verkeerd is in sy weë verag Hom."-(a) Opregtheid (josjer) het eintlik 'n geoetries-simmetriese sin van ,reguit". Tereg vertaal GEMSER ${ }^{26}$ ) „verkeerd-in-sy-weë" met „,krumme Wege”. Die gaan-op-dieweg is hier uitdrukking (Tat-handlung) van 'n religieus-sedelike gesindheid en gaan-op-die-regte-weg kan ons noem die uitdrukking van die ,,integriteit van die persoonlikheid, ${ }^{27}$ ') van 'n sedelik-sterk en -gesonde mens ${ }^{28}$.)Dit is pedagogies bedoel. Die wyses rig hulle meer op die handeling, die daad, die gedrag en verhouding as op wat ons ,gesindheid" noem ${ }^{29}$.)

(b) Die taal en daadwerklike inhoud van bostaande laat ons al dadelik aan ,humanisme" dink. Dit is egter geen imponering van óns humanisme op die Wysheidsliteratuur nie, maar egte uitleg. Die Wysheidsliteratuur is inderdaad die verwoording van die ,religieuse humanisme" van Israel ${ }^{30}$.)

(c) Weer tree die ,veragting" hier as teendeel van die Jahwevrees op.

21) vgl. ook VRIEzEN, a.w. cap. IV.

22) Dit was RuD. OTto wat in sy fenomenologiese analise van ,die heilige" gewys het op die dubbelpolarisme van „,die heilige, die numineuse, die gans andere" wat verskyn as mysterium tremendum en mysterium fascinans, tegelyktydig. Tereg het OTro ook in die psigologie-van-die-vrees algemene byval gevind omdat sy analise so "sachgemäss" is. Ons as christen-teoloë is vry om hierdie terme te gebruik soos bv. EICHRODT en Gemser (N.T.S.), maar ons moet dit helder insien dat ons dit gebruik omdat die saak self (Gods Woord) dit só aan ons gee, en nié omdat dit algemeen-psigologies so treffend en waar is nie.

23) vel. Eichrodt, a.w., p. 1-18, Meinholdt, a.w., p. 58-59 en Hempel, a.w., p. 233.

24) vgl. Spr. $10^{13}$ en Heid. Kategismus, vr. en antw. 3.

25) ToY, I.C.C., p. 269.

96) Sprüche, p. 50 .

27) Toy, p. 281.

28) GEMSER, Spriiche, p. 53.

so) Idem, p.55.

30) SelLIN, Einleitung, p. 134-135 en Isr-jüd. Relgesch., p. 114 v. 
(d) Tox $^{31}$ ) het tereg die Hebreeuse singehalte van hierdie vers weergegee met die samevattende opskrif "Indentity of integrity and piety". Die daad van gaan-op-die-weg is uitdrukking van hierdie houding en wys heen op gebodsonderhouding.

(4) $14^{16}$ : „Die wyse vrees en wyk af van die kwaad, maar die dwase bruis op, en is vol selfvertroue." - (a) Die eerste teëstelling is tussen die ,wyse" en die ,dwase”. Hierdie teenstelling word egter gekwalifiseer deur, en kry sy inhoud van die tweede teenstelling $\mathrm{nl}$. (b) tussen die J a $\mathrm{h}$ w e vresendes en die onbesonne en arrogante mens wat op sigs elf vertrou. Die Hahwevresende is be s o n e , versigt ig en vertrou op Jahwe, en die gevolg is dat hy afwyk van die kwaad; die dwaas is onbesonne, handel impulsief en vertrou nie op Jahwe nie, maar op homself. Die lewe van die een vloei voort uit sy e i e impulse, die lewe van die ander word gereguleer en getem deur Jahwe en sy wet.

(5) $14^{26},{ }^{27}$ : „In die vrees-van-die-Here lê 'n sterk sekerheid; ook vir die kinders van 'n sodanige sal daar 'n toevlug wees. Die vrees-van-dieHere is 'n fontein van die lewe, om van die strikke van die dood af te wyk." - (a)Soos Jahwevrees met rustige sekerheid verbind word, so word dit hier met sterk sekerheid, met toevlug en met le we ( = miskien 'n kwalitatief én kwantitalief lang, rustige, veilige en sekere lewe) verbind. (b) "Sterk sekerheid" en ,,toevlug": In $18^{10}$ word die Naam-van-die-Here ' $n$ sterk vesting genoem. Om op Sy Naam te vertrou en Daarin te glo is vrees-van-die-Here en dit bring s e ke re beskerming en to evlug in nood. (c) „Fontein-van-dielewe": In $13^{14}$ word die onderrig van die wyses ook 'n fontein-v.d.-lewe genoem. Om die Here te vrees en op die onderrig van die wyses ag te gee, is één ding, omdat die wyses die gebod (en sodoende die wil) van die Here sigbaar laat word in hulle onderrig. (d) Die gedagte in hierdie verse is dus dat die Here die Jahwevresendes bes $\mathrm{kerm}$, die goeie laat eet en drink (fontein-v.d.-lewe), hulle bewaar en 'n sekere, lang en rustige bestaan skenk; die dwaas straf $\mathrm{Hy}$ met die dood. Eerbiedige agting op Sy wet en op Hom te vertrou, het die loon van volwaardige en welgeslaagde lewe tot gevolg, is waar-borg (borg = vesting $\left(10^{18}\right)$ ) vir Sy beskerming. Toy vat hierdie twee verse saam met die opskrif: „,The preservative power of godly fear."

(6) $15^{10}$ : „Liewer ' $n$ bietjie $\mathrm{m}$ e $t$ (of: in) die vrees-van-die-Here, as 'n groot skat en onrus daarby." - (a) Hier word die vrees-van-die-Here gestel teenoor ontus. Jahwevrees en vertroue op Hom gee innerlike én uiterlike rus, veiligheid, beskerming en sekerheid. (b) Die tweede teenstelling is "'n-b i e t j i e-met vrees-van-die-Here" en 'n groot-skat-met-onrus-daarby. Dit wys daarop heen dat dit in Israel se heilsverwagting eintlik nie gaan om die romantiese droom van

31) ToY, p. 281. Vgl. ook Pedersen, a.w., p. 201v.v. oor ,integrity" as Israelitiese "Geisteshaltung." 
'n $k$ wantitatief-ryk patriargale tyd nie. Die rus van 'n $k w a$ lit a ti e we Godsverhouding is die beslissende, terwyl rykdom alleen maar 'n g e v o $1 \mathrm{~g}$ hiervan kan wees, maar ook kan uitbly. (c) Deur die parallelie in vs. 16 en 17 word J a h w e v r e e s in vs. 17 ook met l i e f d e verbind.

(7) $15^{33}$ en $22^{4}$ : „Die vrees-van-die-Here is die tug van die Wysheid, en nederigheid gaan die eer vooraf. Die loon van die nederigheid ,en'32) van die vrees-van-die-Here, is rykdom en eer en lewe". - (a) In $1^{7}$ is die vrees-van-die-Here die ,kroon-van-ke $\mathrm{n} n$ i s", in $9^{10}$ die ,kroonvan-die-w y sh e id" en hierdie tug-van-die-wysheid. Die gedagteverhouding wat hieragter lê, is dat ,Jahwevrees" dié korrektief ( $\mathrm{t} \mathrm{u} \mathrm{g}$ ) is, wat die gewone lewe tot lewenskennis (w y s heid) maak. Ander kommentare ${ }^{33}$ ) verander müsar (tug) na müsad (fondament). Hulle doen dit waarskynlik na analogie van $1^{7}$ en $9^{10}$. (b) In albei bg. verse is $\mathrm{n} e$ $\mathrm{d}$ e righ e id, d e e moed en Jahwevrees verbind. Hy wat sy regte plek teenoor Jahwe ken (d.w.s. wat Hom vrees) ken ook sy regte plek teenoor sy $\mathrm{n}$ a a s t e. (c) Jahwevrees het as loon: eer en rykdom, maar veral 'n kwalitatiefryk lewe.

(8) $16^{16}$ : „Deur liefde en trou word die skuld versoen, en deur die vrees-van-die-Here wyk 'n mens af van die kwaad". - (a) Hier staan ,skuld-versoen" parallel met ,,afwyk-van-die-kwaad" en Jahwevrees word in die parallelismus membrorum verbind met 1 i e f d e - e $\mathrm{n}-\mathrm{t} \mathrm{r}$ o $\mathrm{u}$. (b) Die term afwyk-van-die-kwaad gee aan die Jahwevrees hier 'n prakkiesetiese kleur.

(9) $19^{23}$ : „,Die vrees-van-die-Here is tot lewe; en versadig bring 'n mens die nag deur, sonder om deur onheil besoek te word". - - (a) $\mathrm{Toy}^{35}$ ) noem hierdie vers: Piety gives safety. Ons kan dit byna as die grondtoon van Spr. $10^{1}-22^{16}$ neem. Baie keer word Jahwevrees gelykgestel met ,piety" = ,Religion". Die gevolg, die loon daarvan is le we, 'n lang rust ig e lewe met "Hom wat ons alleen in veilighe id laat woon," sodat ons, ,in vrede kan gaan lê en meteens aan die sla a p kan raak" (Psalm $4^{9}$ ). Wie iets begryp van die wilde en vyandige omgewing waarin Israel as vreemdelinge vertoef het, en daarom die vrees in hulle harte vir' $n$ skielike $\mathrm{n}$ agtelike onheil wat hulle sou oorval ${ }^{35 a}$,) wie iets begryp van lsrael se verlange na die vredige rustigheid wat daar kleef aan die Hebreeuse woordjies sjalōm (vrede) en siebet (woning, kulturele woning) in 'n vyandig-wilde land, dié begryp ook iets van die vrees-van-dieHere. (b) Die 1 o o n van die vrees-van-dieHere is lewe, volwaardige en lang lewe, rustige lewe. Hierdie lewe word gekwalifiseer as versadige $\mathrm{rus}$ tigh e id na liggaam en siel, sonder

32) Gemser, Sprüche, p. 64 en Tox, a.w., p. 414.

33) bv. HUMBERT.

34) vgl. Gemser, Sprïche, p.53.

35) Toy, a.w., p. 379.

$\left.{ }^{35} \mathrm{~A}\right) \mathrm{Vgl}$. vir die moderne ooreenkomstige vrees-situasie DAvid RousseT, L'Uniters Concentrationnaire en Les jours de notre mort. 
vrees en skrik vir skielike onheil. ,Versadig bring hulle die n a g deur." Die NAG is die psigologiese "Ort und Zeit" van vrees en skielike nagtelike onheil. Maar hy wat die $\mathrm{Here}$ vrees, bring die nag versadig deur. "Versadig” hou hier die element van d u r a $\mathrm{t} i \mathrm{e}$ we rustigheid in sig teenoor die skie like skrik van buite af in die nag.

\section{Samevattende opmerkinge omtrent hoofst. $10^{1}-22^{16}$.}

(1) Jahwevrees word verbind met kennis, gebodsonderhouding, vertroue en wysheid ${ }^{36}$.)

(2) Die loongedagte is hier prominent. $\operatorname{ToY}^{37}$ ) sê: (The fear of the Lord is) a source of blessing" $\mathrm{en}^{38}$ ) "The main thought is that moral goodness and industry ( = Fear of the Lord) bring prosperity, and wicked. ness indolence and adversity”. Gemser ${ }^{39}$ ) sê: „,Der Lohngedanke ist zweifellos stärker vertreten als das nur einmalige Vorkommen des Ausdrucks $\left(11^{18}\right)$ ahnen lässt. Dússelbe gilt vom Vergeltungsgedanke" ${ }^{40}$ ) Hoewel hierdie loon allerlei materiële seëninge kan insluit, word dit in essensie tog gesien as 'n lang, rustige, volwaardige le w e wat gewoonlik as KWALITATIEF gekwalifiseer word ${ }^{41}$.)

(3) Jahwevrees staan gelyk aan deemoed, ${ }^{42}$ ) 1 i efde en trou ${ }^{43}$ ) en druk 'n vertrouensverhouding uit ${ }^{44}$.) Ons kan hierdie gedagte saam met GEMSER ${ }^{45}$ ) suos volg saamvat: „Das religiöse Verhalten wird ,Furcht vor Jahwe' genannt $\left(10^{27}, 14^{28,27}, 15^{16}, 19^{23}\right)$, der Ausdruck steht parallel mit Demut $\left(15^{33}, 22^{4}\right)$, Liebe und Treue $\left(16^{6}\right)$ und bezeichnet ein Vertrauensverhaltnis $\left(16^{20}, 16^{3}, 18^{10}\right)$ "

(4) Die een wat J a hwe vrees is beson ne en is nie vol selfvertroue nie.

(5) Jahwevrees is 'n DURATIEWE opmerksame vertrouensverhouding (religio, observance) teenoor JAHWE en word psigologies kontrasteer met skielike skrık en vrees vir ander duistere magte wat van-buite-af kom.

(b) Hoofst. 25-29 (Tweede Hoofdeel).

Hier kom die woord „vrees" twee maal voor, maar die Hebreeuse stam is nie ,,jare"' nie, maar pahad $\left(28^{14}\right)$ en harad $\left(29^{25}\right)$.

36) Vgl. $13^{13}, 14^{2}$

37) Tor, p. 164 .

s8) Idem. p. 197.

30) Sprüche, p. 57.

40) Vgl. Idem, p. 51, 53, 55 en 63.

41) Sien Spr. $10^{22}, 13^{13}, 14^{28}$ en $27,15^{16}, 19^{28}$ en $22^{14}$.

42) Spr. $15^{33}, 22^{14}$.

43) Spr. 1618.

44) Spr. 1923, $14^{26}, 14^{27}$.

45) Sprüche, p. 65. 
(1) $28^{14}$ : „Gelukkig is die mens wat gedurig vrees; maar hy wat sy hart verhard, sal in onheil val". - (a) Jahwevrees word hier teenoor "hart-verhard" gestel. „Hart-verhard" is doof wees teenoor die spreke, gebod en wil van God. Hierdie mens ant-woord nie op die Woord van God nie, voel sig nie ver a $\mathrm{t}$ w o ord eli k voor God nie. Hy hoor Gods Woord nie, is ongehoorsaam. Hy gee-nie-ag-op (religio, observance, piety) Gods Woord nie, maar v e $r$ a g Gods Gebod. Die Jahwevresende doen dit wél; hy bely sy sonde en het berou $\left(28^{13}\right)$. (b) Hier word Jahwevrees as 'n duratiewe verhouding (,,gedurig vrees"- $28^{14}$ ) gesien, en miskien lê agter ,,in onheil val $\left(-28^{14}\right)$ iets van die onverwagte skielikheid. (c) Geluk is die gevolg van J a h w e vrees. (d) Dat pahad i.p.v. jarē' hier gebruik word, herinner ons daaraan (aangesien pahad meerendeels werklike skrik wn vrees uitdruk) dat agter - miskien vér agter - die begrip Jahwevrees, ook werklike psigologiese $\mathrm{v} r$ e e s lê.

(2) $29^{25}$ : „Die vrees van die mens span 'n strik, maar hy wat op die Here vertrou, sal beskut word". - - (a) Teenoor die werklike psigologiese $\mathrm{v} \mathrm{r}$ e e $\mathrm{s}$ van die mens vir ander magte, word $\mathrm{J}$ a h w e vrees $(=\mathrm{v}$ e $\mathrm{r}$ t r o u e bv. $\left.29^{25}, 16^{3}, 20,18^{10}\right)$ gestel. (b) Die 1 o o $\mathrm{n}$ van die Jahwevrees is beskutting (en bygevolg 'n rustig e lang lewe.).

(c) Hoofst. $22^{17}-24^{34}$ (Eerste Aanhng).

(i) Ons het hier langer gedagtestrofes en bygevolg breër sinsamehange as bv. in die Eerste Hoofdeel. Dit dien as hulpmiddel tot betere verstaan van die begrip.

(ii) Die doe l van hierdie versameling is Godsvertrou e.$^{46}$ )

(1) 2317: ,Laat jou hart die sondaars nie beny nie, maar die hele dag streef na die vrees-van-die-Here".-(a) Dit is 'n egte wysheidsprobleem wat hier sigbaar word, nl. die probleem van die skynbare voorspoed van die goddeloses. As antwoord hierop word Jahwevrees gestel. Jahwevrees is w y s he id -van-hart $\left(23^{15,19 v}\right)$, is om die hart te rig op die r e g u it w e g $\left(23^{19,6}\right)$; dit gee vastheid aan, en hoop op die toekoms $\left(23^{18}\right)$ omdat dit vertroue is, en word teen le ë begeerte sonder God en ware grond gestel.

(2) $24^{21,22}$ :

Fear thou God and the king,

Anger not either of them;

For the ruin they inflict is sudden,

And the destruction they send unforseen ${ }^{47}$.)

Furchte Jahwe, mein Sohn, und den König

,Gegen beide empöre dich nicht'.

Denn plötzlich kommt von ihnen Verderben

Und Unheil von beiden unversehens ${ }^{48}$.)

46) Gemser, Sprüche, p. $20 . \mathrm{Vgl}$. bv. Spr. $22^{19}$.

17) Toy, p. 450.

48) Gemser, Spriiche, p. 68. 
(a) Toy vat die inhoud van hierdie verse pregnant saam in die opskrif: "Duty of obedience to constituted authorities" en stel sodoende Jahwevrees weer 'n keer gelyk met gehoorsa a mheid, met gehoor-gee-aan, ag-gee-op, rekening-hou-met ( = observance $=$ religio). Jahwevrees kom nie uit in onrustige revolusie (vs. 21), in afguns op die goddeloses (vs. 19 en Spr. 2317) nie, maar is rustige en deemoedige erkenning van 'n mens se plek voor God en die koning, Sy ordening.

(b) Weereens duik die tydsstruktuur wat agter die Jahwevrees en agter die skielike vrees en skrik lê, hier op. Skielike skrik (,plötzlich, unversehens"; ,sudden, unforseen”) sal die goddeloses oorval (vs. 22); hulle het geen rustige toekoms-sekerheid wat die Jahwevrees bied nie (vs. 20 en 22). Hierdie tydsstruktuur lê agter 'n groot gedeelte van die O.T.-se gerigs- en genadeverkondiging. Skielik, voordat hulle tot besinning gekom het (,in die more vroeg"- Hosea $10^{15}$ ), sal die afvalliges se koning ten gronde gaan. Maar die genadeverkondiging wys op 'n duratiewe heilstyd met 'n landelike rustigheid, waarin die mense „, r u s. tig sal woon" (Miga $5^{3}$ ).

\section{(d) Hoofst. $31^{21,30}$ (In Afd. IX).}

(1) $31^{21}:$,Sy (die deugsame vrou) is nie bevrees vir haar huisgesin vanwee die sneeu nie ..."- (a) Vrees (jaré') staan hier gelyk aan ," b e sorg-wees. Die sorge is 'n grondbepaling van ons menswees ${ }^{49}$.) (b) Die feit dat een-en-dieselfde woord jr besorg-wees ( $30^{21}$ ) én religio, Jahwevrees - soos ons gesien het - kan beteken, wys op die bi-valunsie van die begrip ,,vrees" (jarē'). Dieselfe woord (jare') kan dus na twee kante toe uit. Dit kan of Jahwe tot objek hê (dan is die gevolg rus, lewe ens.) óf dit kan eksterne magte tot objek hê (dan is die gevolg onrus, besorgwees ens.). Martha is b e s o $\mathrm{r} g$ oor baie dinge, Maria is besorg oor Jesus d.w.s. glo (Luk. vs. ${ }^{41,42}$. Vgl. Luk. $12^{22 v v}$.).

(2) $31^{30}$ : „Bevalligheid is bedrog, en skoonheid is nietigheid; 'n vrou wat die Here vrees, sy moet geprys word". - (a) Daar bestaan twyfel of die laaste gedeelte oorspronklik is ${ }^{50}$.) (b) Tog beteken Jahwevrees hier vroomheid, Godsvrug, piety. (c) Bevalligheid en skoonheid gaan gou verby, maar Jahwevrees is duratief, hou lank stand.

$$
\begin{gathered}
\text { (e) Hoofst. } 1-9 \text { (Inleidende gedeelte- } \\
\text { Na-eksilies). }
\end{gathered}
$$

Ons gaan hier nie in op fyner historiese skakeringe en die afweeg van die oorspronklikheid van enkele verse nie, maar beskou hierdie versameling as 'n geheel uit die na-eksiliese tyd.

19) Vgl. Martin Heidegger, Sein und Zeit, 6A., Tübingen 1949, j. 180vv. 274-280 en p.30lv.v. Ook hy bring „die Sorge" i.v.m. "Angst" p. 184 . Vir die verband van Sorg en Voorsorg én die seisoene ("Sneeu" in Spr. 3021) vgl. B. J. ENGelbrecht, Die Tydstruktuur in die Gedagtekompleks: Hegel-Kierkegaard Barth, Groningen 1949, p. 83.

${ }^{50}$ ) Vgl. die LXX en Toy, p. 549. 
(1) $1^{7}$ : „Die vrees-van-die-Here is die ,kroon' van kennis; sotte verag wysheid en tug". - (a) GeMseR ${ }^{51}$ ) noem $1^{7-9}$,die Empfehlung der Weisheit", die hooftema van die hele versameling, terwyl Toy ${ }^{52}$ ) dit "the Motto" noem. (b) Miskien mag in hierdie verse 'n apologetiese kleur deurgevleg wees, maar tog staan Jahwevrees en Wysheid nie teenoor mekaar nie, maar gaan hulle veeleer hand-aan-hand met mekaar. Die gebruik van Jahwe i.p.v. Elohim gee aan die Spreuke'n besondere kleur. ${ }^{53}$ )

(c) GeMser noem die sotte diegene wat in hulle lewe nie met God en Sy gebod rekening hou nie. Die Jahwevresendes gee-ag-op Hom, en deur die ,tug" daarvan word die lewe vanuit sy alledaagsheid tot 1 e w e n s kun s (= Wysheid) voor God verhef.

(d) Toy verstaan tereg onder ,beginsel” (Afrik. Vertaling) nie „principium” nie, maar „Wisdoms choisiest feature, its foremost and essential element". Ons eie vertaling met „kroon" behou nog 'n herinneringsband met die Hebreeuse stam ,rōsj (= hoof)", terwyl die Afrikaanse woord „,kroon" wel die ,,voortreflikste”, ,die beste” beteken bv. in uitdrukkinge soos ,die-kroon-span", ,die kroon van die waatlemoen" ens.

Die gevoel wat oorspronklik v r e e s, ,dread of the divine anger" was, het hier verskuif na e e r bied (Duits: Ehr-furcht) vir die goddelike gebod. Vgl. verder ons kommentaar oor Spr. $13^{13}$,e.

(2) $1^{20-33}$ : (a) Hierdie perikoop word genoem ,,die Weisheit als Busspredigerin ${ }^{54 " .)}$ Dit handel in hierdie verse oor die skielike skrik, benoudheid en angs wat die eenvoudiges ,,soos onweer sal o o r v a l (vs. 27) „omdat hulle die kennis gehaat het en die Jahwevrees nie verkies het nie, van die wysheid se raad nie wou weet nie, en al haar teregwysinge verag het" (vs. 29-30). In plaas van skielike angs, vrees en benoudheid, sal diegene wat ag-gee-op die wysheid se rigsnoere (d.w.s. diegene wat Jahwe v re e s), veilig woon en rustig wees teenoor die skrik van die onheil (vs. 33). En so tree die tydsfiguur waarop ons gewys het, weer hier tevoorskyn.

(b) Ke n n is van Jahwe word hier parallel gebruik met Jahwe$v$ r e e $s$ en e i e-geregtigheid en e i e-wysheid word teenoor die rigsnoere van die Wysheid (= Kennis = Jahwevrees) gestel.

(3) $2^{5}$ : Hierdie hoofstuk vorm 'n eenheid wat op die ,vyfvoudige seën van Wysheid" ${ }^{55}$ ) wys, en waarvan die grootste seën die „,verstaan van die vrees-van-die-Here, en die vind van kennisvan-God" is.

(a) Hier word Godskennis en Jahwevrees weereens gelykgestel. $\mathrm{Kenn}$ is is vir Israel 'n sekere vertroudheid wat uit per-

51) Sprïche, p. 13.

31) ToY, a.w., p. 10.

s3) GeMSER, Sprüche, p. 21.

54) Idem, p. 16.

s5) Idem, p. 18. 
soonlike verkeer ontstaan ${ }^{56}$.) Die seën van die $W_{y s h e i d}=$ Jahwevrees $=$ oorleg (vs. 11) $=$ gelei-word op die regte (= reguit) weg vs. 9) wat na 'n to e kom s lei. Hierdie toekoms-verwagting word in Hebreërs $11^{1,2,14-18}$ met g e l o of gelykgestel. Dat dit hier nog i.v.m. gaan-op-die-reguit-weg (= gebodsonderhouding) gebring word, wys daarop dat ons hier in Spreuke nog in die bedeling van die wet is. J a h w e v r e e s (Spreuke) is dus g e lo of (Hebreërs II). Dat die woord v r e e $s$ hier gebruik word, wys dat die woord wat dieselfde saak aanduie as geloof, hier ' $n$ ander agtergrond het, en 'n ander psigologiese gehalte. Die saak van die ,toekoms" kan ons so stel: Jahwe sal Self aan die einde van die dae na hulle toe kom (d.i. hulle toe-koms wees), wat Hóm v r e e s. Vir diegene wat op hulle-s e $1 \mathrm{f}$ en ander magte vertrou, sal die ander magte as "Nikse" ontmasker word in die laaste van die dae en dan sal hulle werklik bevrees word.

(b) Tereg merk GemSER ${ }^{57}$ ) in die verband op dat 'n p lo t s e l ing e, onvoorbereide dood die goddeloses sal oorval (Spr. $1^{26 \mathrm{v}}$, Psalm 918, $73^{19}$, Job $4^{19-21}$ ) en dat Elifas (Job $5^{19-27}$ ) die rust ig e lewe van dit Godsvresendes beskryf, dat Jahwevrees en Wysheid 'n paradys'se vrede moontlik maak.

(4) $3^{7}$ : In hierdie perikoop (v.5-12) word 4 wyses van betoning van Jahwevrees aanbeveel nl. vertroue op God (vs. 5), de e moed voor God, die ve re ring van God met die gawes van jou besit (v's. 9-10) en die erkenning van die tugtigende God (vs. 11). Hierteenoor word valse eievertroue op eie insig, die autonomie i.p.v. die erkenning van die teonomie, gestel. Beide Gemser. en Toy ${ }^{58}$ ) meen dat in vs. 7 (, Wees nie wys in jou eie oë nie, vrees-die-Here en wyk af van die kwaad") die Jahwevrees en egte sedelikheid ident is. (Vgl. Job1 ${ }^{1}, 28^{28}$ en Spr. $\left.16^{6}\right)$.

(a) J a hwe vre e s én wysheid én afwyk-van-die-kwaad word hier ident en teenoor e i e -wysheid gestel. Die egte bron van ons lewenskennis is nie ons eie insig nie, maar kennis-van-die-Here. Om dit te er-ken, is Jahwevrees,

(b) Die gevolg van die Jahwevrees is die seën van 'n gelukkige, lang en ongestoorde lewe (vs. 1 en 2).

(5) $8^{13}$ : „Die vrees-van-die-Here is om te haat wat sleg is; hoogmoed en trotsheid, 'n slegte wandel en 'n huigelagtige mond haat ek ...."

(a) Deur 'n histories-kritiese probleem rondom die huidige stand van die vers ${ }^{59}$,) kan ons by die versigtige opmerking van Prof. Gemser aansluit: „Wenn 13 ursprunglich ist, besagt er dass die Weisheit (und Gottesfurcht - unser Zusatz) mit Demut und Aufrichtigkeit verbunden ist."

58) Idem, p. 18 en Prof. Dr. G. v.D. Leeuw, Inleiding tot d. Theologie, 1ste, Uitg. p. 19,2 de Uitg., p. 22.

57) Sprüche, p. 23 en 22.

58) Idem, p. 21, Tor, p. 61.

so) ToY, p. 164, Gemser, Sprüche, p. 37. 
(6) $9^{10}$ : „Die kroon van die Wysheid is die vrees-van-die-Here, en kennis van die Heilige is verstand."

(a) Hier word Jahwevrees, Jahwe-kennis en Wysheid parallel gestel. Jahwevrees en -kennis is nie bloot teoretiese en kultiese groothede nie, maar is 'n prakties-eties-eksistensiële lewensvorm en lewensnorm wat sig uit in lewenskuns, in wysheid. (b) Jahwevrees kan hier samevattend as onderd a n igh e i d ${ }^{60}$,), ,reverance", ,obedience" genoem word.

(c) Opvallend is dat in hierdie vers nie v r e e $\mathrm{s}$-vir-die- $\mathrm{H}$ e i 1 i g e nie, maar kennis-van-die- Heilige voorkom, en parallel gestel word met Jahwevrees.

Samevattende opmerkinge omtrent Hoofst. 1-9.

(1)(i) J a h we v r e e s (wat GeMSER ${ }^{61}$ ) gewoonweg „Religion" noem), (ii) ken $\mathrm{n}$ is en (iii) Godsvertroue (wat almal uit persoonlike verkeer ontstaan en daarin hulle bestaan vind) asook (iv) wysheid (wat 'n etiese lewensnorm en lewensvorm uitdruk) word as sinonieme gebruik. (b) Die J a we vresende (wat gedurig ag-gee-op God en Sy gebod en deemoedig en opreg is) word teenoor die „sotte" gestel wat e i e -wys is, wat nie ag-gee-op Gods Woord (= Toraonderrig van wyses) en wat nie afwyk van die kwaad nie. (c) Die lo o n van die Jahwevrees is ' $n$ lang en rustig-ongestoorde le we, en dié van die "sotte" is sk i e like onheil. (d) Jahwevrees tree hier veral as onderdanigheid (= reverence = obedience - Toy), as eerbiedige (ehr-fürchtige) gehoorsaamheid te voorskyn.

\section{B. DIE BOEK JOB}

Hoewel Job deur probleemstelling en inhoud onmiskenbaar in die Literaturgattung van die Wysheidsliteratuur val, vind ons in hierdie bynaprofetiese „protes teen die oorgelewerde Wysheid" tog 'n geheel-ander geestesklimaat, styl, en miskien ook 'n geheel-ander antwoord op die Wysheidsvrae as in Spreuke en Prediker.

Aangesien die vrees-van-die-Here 'n verwoording is van 'n bepaalde (en tog ryk-geskakeerde) verhoudingswyse van die mens teenoor God en Sy Gebod, sal dit vir die helderder verstaan van die Jahwevrees goed wees om te sien op welke bepaalde wyse God en mens in die boek Job tot openbaring kom.

Saam met OTTO $^{62}$ ) kan ons hier die volgende opmerking waag: Verwante uitdrukkings vir Gods heiligheid is Sy grimmigheid, toorn

\footnotetext{
${ }^{\circ 0)}$ Sprïche, p. 41.

c1) Idem, p. 17.

(2) Rud OTto, Das Heilige, 15A., p. 101-107.
} 
en ywer ${ }^{63}$.) Dit druk nie net die vergeldende geregtigheid van God uit nie, maar ook Sy tremendum en majestas; die mysterium en augustum van Gods itrasionele wese. Dit staan veral i.v.m. die "l e wende God" met Sy toorn, liefde e.a. affekte wat teen die filosofiese God gestel word. Job stel die werklike, lewende God in die akte van Sy openbaring teen die filosofiese Gods - b e e ld van sy vriende. Hierdie affekte is nie gewone antropomorfismes nie, maar ideogrammatiese simbole van die lewende, gans-andere God - „, die God van Abraham, Isak en Jacob”. ${ }^{64}$ )

Met seldsame suiwerheid verbind die boek Job in Hoofst. 38 die element van die mirum met die element van die augustum. Job het naamlik met sy vriende getwis oor die weë van God met die mens, en het klaarblyklik gelyk gekry teenoor hulle. Hulle moes teenoor Job se eksistensiële spreekwyse verstom staan. Maar dan neem God die verdediging op Sigself en Hy doen dit só dat Job moet erken dat hy oorwin en innerlik oortuig is. Die Teofanie wat tegelykertyd ook Teodikê is, wys op die wonderbare, op die suiwer gestalte van Gods mysterium heen. Die heenwysing na die seldsaam-wonderlike en raaiselagtige skeppingsdinge (arend, volstruishenne, monsterdiere) is heenwysing op die mysterium fascinans én tremendum wat die siel in die diepte aangryp en tegelykertyd aantrek én afstoot ${ }^{65}$.) Dit is heenwysing na die demoniese geheelandersheid. Die mirum is hier tegelyk ook admirandum en adorandum. Nie in die dimensie van ,hoor-sê" (Job $42^{5}$ - d.w.s. die abstrakte spreke van Job se vriende én sy eie eksistensiële spreke) maar in die gebied van die „,sien" (die Teofanie) en ,,bestaan" (bv. paniese angs) word die ant-woord op die wysheidsvraag verwerf.

Opsommend kan ons sê dat God in die boek Job openbaar word as die lewende God (met Sy heilige wese as mysterium fascinans et tremendum met die elemente van majestas, augustum en mirum) as die Numineuse wat gestel word teenoor die filosofiese argumente-god, die berekenbare God van die ,spotters".

Hier in Job, soos in alle Wysheidsliteratuur, het 'n merkwaardige verskuiwing (,transposisie”) van die groothede: „vrees” en ,angs" plaasgevind. In die historiese gedeelte van die O.T. was dit vrees en angs van die volk, hoofsaaklik vir die vyand rondom en buite hulle; hier in die Wysheidsliteratuur is dit die ,vrees" en ,,angs" van die e n k e l in g in sy enkel-bestaan voor God.

Teenoor God wat op hierdie wyse in Job tot openbaring kom, staan die brose en nietige skepsel wat van klei afgeknyp is ${ }^{66}$,) die onreine en verganklike ${ }^{67}$.) Dit is dan ook geen wonder nie, dat die hele skaal van

os) Vgl. Jes. 6 en $40-66$.

64) PASCAL gebruik hierdie uitdrukking, wat hy aan die Skrif ontleen, in 'n soortgelyke maar moderner filosofiese situasie as Job. Deur die heenwysing na die $h$ e il s . g e s $\mathrm{k}$ i e d e $\mathrm{n}$ is wys Pascal op die objektiewe en aktuele karakter van Gods openbaring teenoor die subjektiewe en algemene karakter van die filosofiese "I d e e".

B5) BleEkER, T.U., Job, p. 46, 47.

68) Job. $33^{6}$.

b7) Job $14^{1 \mathrm{v} . \mathrm{v}}$. 
verhoudingswyses van die mens in sy staan-voor-God (siddering, verskrikking, skrik, vrees, huiwering, ontsag) in Job verwoord word. Hiervoor verskillende Hebreeuse woorde gebruik bv. phd, hrd, $b^{c} t$ en jr'.

In Spreuke gaan dit om rustige, ongestoorde lewe - oor lewenswysheid; in Prediker is Kohelet wel gevang in die net van ewige kom-engaan, en hy spreek dit uit in 'n gedempte toon. Aan die einde van sy boek (Hoofst. $12^{13}$ ) beveel hy tog die genieting van die lewe-as-gawe-vanGod aan; maar in Job gaan dit om die mens in sy eksistensiële staan voor God, en hy verwoord dit in die terme: onrus, ontsag, vrees, angs, skrik, verskrikking en siddering.

\section{(a) Phd en sy Afleidinge.}

Hierdie Hebreeuse woord is ' $n$ sterk woord vir ,,vrees". In $3^{25}$ kom dit gewoonweg voor as ,,bang-wees”. Dit word as ,,siddering” en ,skrik” by die verskyning van Gods Woord in die naggesig teenoor die kalmte en rus gestel in $4^{14}$. In $13^{11}$ word dit ook gebruik as ,skrik" en ,,angs" voor God in „His glorious majesty ..." Dit is ,the $\mathrm{dread}$ inspired by Yahwe when He rised to judgement ${ }^{68}$. In Hoofst. $23^{15,16}$ kom hierdie stam voor as ,,bang-wees" vir God vanweë Sy vreeslike mag in besluit en handeling. Al wandel die mens opreg, wek die onbekendheid met die gang van Gods oordele ook phd bv. Hoofst. $31^{23}$.

\section{(b) JR' eN sY Afleidinge}

I. As uitdrukking van die gewone psigologiese vreeshouding (maar nogtans in die gebied van die Godsverhouding).

1. $5^{21,22}$ : „As die tong gésel, word jy weggesteek; en jy hoef nie te vrees vir die verwoesting wat kom nie. Oor verwoesting en broodgebrek sal jy lag, en vir die wilde diere van die aarde hoef jy nie te vrees nie." Hier word jr' duidelik gebruik om die gewone psigologiese vrees, $\mathrm{nl}$. ", ba n g-w e e s-vi r", uit te druk. Daar word geimpliseer: As jy die Here vrees (d.w.s. nie die tugtiging van die Almagtige verwerp nie Hoofst. $5^{17}$ ) dan hoef jy nie te vrees vir ander vreeswekkende dinge en magte wat van buite af kom nie. Só word bv. in Exodus $20^{20}$ dieselfde woord (jr') gebruik, om beide die psigologiese vrees, én die Godsverhouding aan te dui. D it is belangrik vir die navorsing en verstaan van die „oorsprong" en geskiedenis van die begrip: Jahwevrees.

2. $6^{21,6}$ : , Julle sien verskrikking, en hulle het gevrees"- BLEEKER ${ }^{69}$ ) vertaal hier met die minder-skerp woord: „schuwt". Vir die betekenis betekenis van hierdie vers, sien $5^{21,22}$.

68) Driver and Gray, I.C.C. p. 127.

"D) BleEker, T.U., ter plaatse. 
3. $9^{35}$ : Die inhoud van hierdie vers is vrees-vir-God (in werklike sin) omdat hy tugtig.

4. $11^{15,6}$ : „En jy sal vasstaan sonder om te vrees." - Die sin is hier ook ,b b ng-we e s", d.w.s.: As jy jou hart berei, jou hande uitbrei na Hóm en nie meer onreg doen nie (m.a.w. as jy die Here v r e e s) hoef jy nie vir Hom, maar ook nie vir ander duister magte, bang te wees, bevrees te wees nie.

5. 3722: Die ontsagwekkende majesteit van God en Sy skepping word hier uitgedruk met die stam jr' nl. nôrd'. 'n Plek waar die Here teenwoordig is in Sy woon en werk, is nôrâ'. Vgl. bv. Gen. $28^{16 \text { en } 17}$.

(b) $32^{6}$ : Hier sê Elihu dat hy beskroomd (= bevrees) was om sy kennis mee te deel omdat hy 'n jongeling tussen die grysaards is. Die oud-oosterse e e rbied (Duits: Ehr-furcht) van die jong mens teenoor sy ouere en meerdere, word hier dus met $j r$ ' aangedui.

Opsommend kan ons dus hier sê, dat die woord $j r^{\prime}(=$ vrees $)$ in bostaande plekke werklike psigologiese vrees nl. bang-wees-vir beteken bv. vir God $\left(9^{35}\right)$, vir die majestueuse skepping $\left(37^{22}\right)$. Dit beteken in $32^{6}$ ook skugter-skaam e e r bi ed.

\section{Jr' as uitdrukking van die Godsverhouding.}

1. 1.1,8: „'n Man, vroom en opreg, Godvresend en wat afwyk van die kwaad." - (a) BLEEKER vertaal „,vroom” met ,onberispelijk”, ${ }^{70}$ ) ,gaaf", ,,vlekkeloos". ${ }^{71}$ ) Die Hebreeuse stam tm beteken: vry van gebrek, perfek (in relatiewe sin), kompleet. As substantief kan 'n mens dit vertaal met , i n tegriteit $"{ }^{72}$ ) In verbinding met $d r k(=\text { pad, weg })^{73}$,) slaan dit op perfekte gedrag, beteken dit: ,wandelin-die-wet-en-weg-van-die-Here", 74 .)

( $b$ O p r e g d.w.s. jsjr besit ook die geometries- $\mathrm{s}$ i m m e trie s e sin van $t m d r k$ en beteken ook , 1 o j a a 1 - w e e s".

(c) Die vrees-van-God $\left(1^{1}, 1^{8}\right)$, die vrees-van-die-Almagtige $\left(6^{14}\right)$ én afwyk-van-die-kwaad (d.i. vermyding van elke geleentheid van kwaad) word hier en in Hoofst. $28^{28}$ (vgl. ook Spr. $3^{7}$ ) baie nou met mekaar verbind. Die vrees-van-die-Here is hier (en oral in die Wysheidsliteratuur) die regulatiewe beginsel op die lewensweg, sodat godsdiens en sedelikheid twee sye van dieselfde saak is.

(d) BLEEKER ${ }^{75}$ ) maak die volgende verbinding: ,Job is oprecht en hij is dat, omdat hij God vreest en zijn Godsvrucht (= Jahwevrees) word gewaarmerkt door zijn afkeer van al wat slecht is ...."

70) T.U., p. 51 .

71) T.U., p. 106.

72) Driver and Gray, p. 3-4

73) Vgl. Gen. $17^{1}$ en Job. $4^{6}$.

74) Vgl. Driver and Gray, p. 3.

75) T.U., p. 106. 
(e) Samevattend kan ons sê dat Job se karakter in die proloog saamgevat word as opregte vroomheid $=$ Jahwevrees $=$ erkenning van die on tsaglike verhewe $n$ heid van God, en tegelyk daarmee die erkennig van die mens $\mathrm{se}$ e ie $\mathrm{n}$ ietigheid en kleinheid en juis daarom sy af hanklikheid van $\mathrm{Hom}$. Ook die I.C.C. ${ }^{76}$ ) beskryf die karakter van die Godsvresende Job as ",piety".

2. $1^{9,6}$ : „Is dit verniet dat Job God vrees?" - (a) Volgens BleEKeR ${ }^{77}$ ) makk Satan hier die verwyt dat Job se Godsvrees (wat in Job $1^{1,},{ }^{8}$ beskryf word), nie belangeloos is nie; dat dit eudemonisties gekleurd is. Ons kan hier sê: Satan verwissel oorsaak (Godsvrees) en gevolg (seëninge) Satan sê: Job is nie geseënd omdat hy God vrees nie, maar hy vrees God alleen maar omdat hy geseën word.

(b) Godsvrees beteken hier dus vroomheid, „piety" en seën is die g e v o lg daarvan.

3. $4^{6}, 15^{4}, 22^{4}:$,Is jou Godsvrees (BLEEKER ${ }^{78}$ : Godsdienst) nie jou hoop, en jou ,vrome wandel' (=tm $d r k$ ) jou verwagting nie?" ,Ja, jy breek die Godsvrees (BLEEKER ${ }^{79}$ : Godsurucht) af, en verstoor die stille oordenking voor die aangesig van God." „Is dit oor jou Godsvrees (BLEEKER ${ }^{80}$ : Godsurucht) dat Hy jou bestraf, dat Hy met jou in die gereg gaan?" (a) Alhoewel daar in die oorspronklike teks alleen „,vrees" (=jr'h) staan, is dit bv. deur paralelle uitdrukkinge in die samehange van hierdie verse duidelik, dat Gods-vrees (= Godsdienst, Godsvrucht, Religion) bedoel word.

(b) Opmerklik is dat hierdie drie tekste in die redevoeringe van Elifas voorkom.

(c) In $4^{6}$ word Godsvrees (Blfeker: Godsdienst) en opregte, onberispelike wandel feitelik gelykgestel. Weer is die Godsvrees die korrektief wat van die alledaagse en gewone lewe eties-hoogstaande lewensk u n s maak. Hierdie lewenskuns gee aan die lewe 'n wyer perspektief, gee daaraan 'n toekoms, 'n hoop en 'n verwagting. Dit voeg by die lewe die vertrouenselement van seën en vergelding van die lewende God. ${ }^{\mathbf{8}}$.)

(d) In $15^{14}$ word Godsvrees en still e oordenking, ,stil zijn; bij Hem met de gedachten vertoeven" ${ }^{82}$ ) verbind. Hier dink ons aan die Psalmwoord: „En hy oordink Sy wet dag en nag". ${ }^{83}$ ) Volgens BleEker kan die afbreking van die Gods v r e e s gelykgestel word met die ondermyning van die o $\mathrm{nts}$ a vir God.

(e) In $22^{4}$ het Godsvrees dieselfde betekenis as hierbo, en ongetwyfeld lê die gedagte hieragter dat Godsvrees ons vrywaar van straf en gerig.

\footnotetext{
i0) Driver and Gray, p. 13.

77) T.U., p. 108.

r8) T.U., p. 54 .

80) T.U., p. 77.

81) Vgl. ook Spr. $14^{26,27}$ en Ps. $119^{137}$.

82) BLEEKER, ter plaatse.

83) Ps. $1^{2}, 16^{7}, 119^{97}$.
} 
4. $6^{14}$ : „Wie zijn vriend medelijden onthoudt, verzaakt de vreesdes-Almachtigen." ${ }^{84}$ ) - (a) Die Godsvrees uit sig hier in mens1 i e we nd heid.

(b) Die I.C.C. vertaal vrees-vir-die-Almagtige met „Religion” soos in Job $4^{6}, 15^{4}, 22^{4}$.

5. 2828: „Maar vir die mens het $\mathrm{Hy}$ gesê: Kyk, die vrees-van-dieHere is wysheid, en om van die kwaad af te wyk, is verstand" (= inzicht BleEker). - - (a) Sommige eksegete, bv. BleEker, meen dat hierdie vers 'n toevoeging is op grond van Spreuke 8.

(b) Hier word die vrees-van-die-Here parallel gestel met w y s h e id, a f w y k-van-die-kwa ad en in sig.

(c) As ons die huidige samehang van die teks neem soos dit is, blyk dit dat die Wysheid-van-God ook saamhang met Sy $\mathrm{skepping} \mathrm{mag}$, én dat die wysheid-van-die-mens nou verbonde is met die vrees-van-die-Here. Hieruit word die religie use inhoud van die Wysheid in samehang met sy e ti e se in h oud ook duidelik, sodat die samehang: geregtigheid, wysheid en Jahwevrees begryplik word. ${ }^{85}$ )

6. $37^{24}$ : „Daarom moeten die menschen Hem vreezen; doch geen der wijzen zelfs kan Hem zien." $\left.{ }^{86}\right)$ - (a) Die gedagtegang waarin hierdie vers staan, is die volgende: „Omdat God in Zich vereenigt onweerstaanbare macht en onkreukbare rechtvaardigheid, eeren Hem de menschen, in plaats van aan te klagen". ${ }^{87}$ )

(b) So word Godsvrees-te-hê en $\mathrm{Hom}$ - te-e er deur BLEEKER as sinomieme gebruik.

(c) Ons kan die verskillende gegewenhede in hierdie vers as volg verbind: God is onweerstaanbaar en onverstaanbaar magtig, bv. in Sy skeppingsmag. Tog kreuk Hy die reg en geregtigheid nie, maar Hy openbaar Hom in Sy gebooie (= wet) as dié Een wat Hom aan orde en reëlmaat hou - vir diegene wat Hom vrees, ten goede; vir diegene wat onagsaam is, ten kwade:

(d) "God-te-sien" is 'n eskatologiese grootheid; „Hom-te-vrees" is die paslike verhoudingswyse van die mens op aarde.

\section{Opsommende aanmerkinge oor die begrip Godsurees by Job.}

1. In hierdie ,profetiese protes teen die oorgelewerde Wysheid" staan die enkeling eksistensiëel-aangegrepe ${ }^{88}$ ) voor God in Sy openbaring. In hierdie aangegrepenheid tree weer dinge tevoorskyn wat lankal reeds

84) Vgl. BleEker, T.U., p. 57; I.C.C., p. 132.

85) Vgl. hieroor Gemser, Sprüche, p. 1 .

86) BLEEKER, T.U., p. 97; vgl. ook I.C.C. wat in dié sin vertaal.

87) BLEEKER, T.U., p. 226.

88) Ons gebruik die woord ,existensiëel" hier nie in sy „,eksistensfilosofiese” samehange nie - daar het dit trouens ook verskillende en selfs teenoorgestelde begripswaardes -, maar veeleer in die KiERKEGAARDSE sin waar die enkeling voor God staan en dit sy hele persoon, bestaan en menswee. 
gaan skuil het agter vaste geordendheid en begrippe bv. die werklike ontmoeting met die lewende God. Wat alleen maar van hoor-s $\hat{e}^{89}$ ) uit die geskiedenis bekend was, gebeur hier weer werklik. En hierdie feit is baie belangrik, veral wat betref die ontstaan en geskiedenis van hierdie begrip. In hierdie situasie tree weer die oer-verwantskap van die vreesvan-die-Here en die gewone vrees na vore. Die stam phd wat ons met s k rik kan vertaal, kom voor in $3^{35}, 4^{14}, 13^{11}, 23^{15}$ en 16 en $31^{23}$. Die stam $j r^{\prime}$ druk in $5^{21,22}, 6^{21}, 9^{35}, 11^{15}$ en $32^{6}$ gewone psigologiese vrees (bang-wees) uit, maar juis hierdie selfde stam druk in $1^{1,8,9} ; 4^{6}, 15^{4}, 22^{4}$; $6^{14}, 28^{28}$ en $37^{24}$ Jahwevrees uit, 'n bepaalde verhouding met God.

2. Jr' verwoord in $9^{35}$ en $37^{22-24}$ selfs psigologiese bangwees voor God. In $32^{6}$ beteken dit beskeie-, beskroomdwees.

3(a). $J r^{\prime}$ beteken in $1^{1},{ }^{8}$ onberispelik-wees, reguit (jsjr) gaan op die lewensweg, afwyk van die kwaad. Dit beteken die erkenning van die ontsagwekkende majesteit van die Here God in fisiese en sedelike sin $\left(1^{1,8,9}\right.$ en $\left.37^{22-24}\right)$, en bygevolg die wete van die nietige mens se afhanklikheid, wat weer met die sedelikheid en mensliewendheid $\left(1^{1,8} 4^{6}, 6^{14}, 28^{28}\right)$ verbind word. So gesien is die Godsvrees (Godsdiens, „Religion”) die regulatiewe beginsel van die mens se lewe.

(b) Die Goddelike seën is die 1 o o n van die Godsvrees $\left(1^{9}, 22^{4}\right)$. Maar dan moet ons hierby onthou dat Job juis hierteen polemiseer.

(c) Verder word Godsvrees in $28^{28}$ (vgl. Pred. $12^{13}$ ) met wysheid ,verstand (insig) en sedelikheid verbind, asook met stille oordenking $\left(15^{4}\right)$.

\section{DIE BOEK PREDIKER}

\section{(a) INLEIDING.}

Hertzberg merk in sy kommentaar ${ }^{90}$ ) op dat Heine Prediker as „Hohelied der Skepsis" omskryf, terwyl Franz Delitzsch dit weer „Hohelied der Gottesfurcht" noem. Prof. Gemser ${ }^{91}$ ) karakteriseer Prediker as die "lewensbieg van 'n teleurgestelde". Met kenmerkende sekuurheid beskryf hy die grondtoon van Prediker as ,pessimisties”, terwyl die gees van sy boek ,in zijn levenswaardering kritisch-skeptisch, in zijn wereldbeschouwing deterministisch-fatalistisch, in zijn gedragsleer eudaemonistisch" is. Prediker gaan "over de onwaarde van het bestaan". ${ }^{92}$ ) En alhoewel hier in Westerse woorde en begrippe geworstel word, om 'n Oosterse boek te tipeer, gee hierdie opmerkinge tog die sfeer van die boek goed weer.

Eksegete ${ }^{93}$ ) meen dat die ,slotspreuke" heel waarskynlik latere toetoevoegings is, vermoedelik deur 'n Chasid. Ons het egter die boek

8v) Job $40^{5}$.

s) p. 32 .

81) T.U., II, p. 58.

12) Idem, p. 57.

") Bv. Barton, I.C.C. 
(as geheel) se ontstaan in sy "huidige" vorm histories-krities probeer bepaal, en daarom interesseer dié vorm ons hier.

Opmerklik is dat die Naam E lo hi m hier gebruik word, en nie $\mathrm{J}$ a h w e nie.

\section{(b) EKSEGeSe.}

1. $3^{14}$ : „Ek het ingesien dat alles wat God doen, vir ewig sal bestaan; daar kan niks bygevoeg en daar kan niks weggeneem word nie, en God het dit so gemaak dat hulle moet vrees voor Sy aangesig." - (a) HerTzBERG $^{94}$ ) meen dat dit God se doel is om deur Sy werke die mens die a $f$. $s t a n d t u s s e n$ Hom en die mens te laat besef, d.w.s. Hom te vrees.

(b) GeMSeR ${ }^{95}$ ) sê dat die Godsplan by die vaste gang van die dinge juis só is, dat die mens slegs in on ts a g d a a ronder $\mathrm{kan} \mathrm{buig}$.

2. $5^{6}$ : "Want by baie drome en baie woorde is daar ook nietigheid, maar vrees God." - In die voorafgaande verse waarsku die Prediker teen vele woorde by die gebed en teen onbesonne geloftes wat maar al te lig nie uitgevoer word nie. In die lig hiervan verskyn Godsvrees as e e rbied en piëteit by die gebed en besonnenheid by die gelofte. Die grondtoon hier is die ,pietas”, die „Ehrfurcht" voor die verhe we God. Vgl. $5^{1}:$,... want God is in die hemel, en jy op die aarde; daarom moet jou woorde min wees."

3. $7^{18}$ : „Dit is goed dat jy aan die een vashou en ook van die ander jou hand nie aftrek nie; want dié wat God vrees, ontkom aan albei"Prof. Gemser vertaal: ,voldoen aan beide”. Die sin van hierdie vers is: Vermaning teen oormoed en aanbeveling van ,ontzag voor God"96.) Matigheid $^{97}$ ) is die middeweg bewandel deur ontsag vir God, deur Godsvrees.

4. 812,13: „Hoewel 'n sondaar honderdmaal kwaaddoen en tog lank leef, weet ek dat dit goed sal gaan met dié wat God vrees, wat vrees voor Sy aangesig, en dit nie goed sal gaan met die goddelose, en hy die dae nie sal verleng soos 'n skaduwee nie, omdat hy voor die aangesig van God nie vrees nie." ${ }^{\prime 9}$ ) - (a) „Vrees-voor-Sy-aangesig" kan hier óf stilistiese byvoeging wees by ,vrees-van-die-Here", óf dit kan hier werklike vrees beteken, maar dan religieus gekleurd nl. on t $s$ a g, pi ë te it, $\mathrm{kl}$ e in he idge voel. Indien laasgenoemde die geval is, dan blyk hieruit weer die oer-verband tussen die vrees-van-die-Here en werklike vrees.

(b) Weer blyk uit hierdie vers die gedagte van die 1 o o n van 'n rustige kwalitatief-lang le w e vir die Godvresendes.

es) p. 89 .

s) T.U., II, p. 105.

๑) T.U., p. 120.

97) Idem, p. 139; vgl. Pred. 1212.

98) Vgl. die vertaling van Gemser op p. 84 en van Hertzberg op p. 147 asook die uitleg van GEMSER OD p. 124v. 
5. $12^{13}$ : „Die hoofsaak van alles wat ons gehoor het, is: Vrees God en onderhou sy gebooie, want dit is die hele mens." - (a) Die regte vertaling van: "want dit is die hele mens", skyn tog te wees. „want dit is die saak van elke mens". ${ }^{99}$ )

(b) GeMSER noem hierdie slot 'n ,summa summarum". In Spr. $1^{7}$ word die vrees-van-die-Here die beginsel van die kennis ( e n wy s heid) genoem, in $9^{10}$ die beginsel van wysheid en in $15^{33}$ wil sommige vertaal die fond a m e $\mathrm{t}$ (óf: tug) van die wysheid, en hier is die Godsvrees die sluitsteen van die wysheid, „,der Weisheit letzten Schluss" ${ }^{100}$.) Hoewel ons van die vertalinge kan verskil, lê die gedagte ongetwyfeld hieragter dat die vrees-van-die-Here die keur, die kroon van die wysheid is.

(b) Weer word hierin die Godsvrees en die onderhouding van die gebooie nou saamverbind. "Gebooie" beteken hier: Die spreke van God as enigste sedelike rigsnoer van die lewe.

(d) Netsoos in Job $37^{24}$ en $28^{28}$ word die vrees-van-die-Here as die passendste houding van die mens in sy ,,diesseitige" bestaan beskryf.

(c) Opsommende aanmerkinge oor die Godsvrees in die boek Prediker.

1. Opmerklik is die vermyding van die Jahwenaam in Prediker. Dit skyn opsetlik te wees. Daarom mis die term Godsvrees in Prediker dan ook die intimiteit van die Jahweverhouding. Jahwe is die liefdevolle Verbondsgod wat sy gebooie as openbaring van Sy wil gegee het en gehoorsaamheid aan Sy wil eis. Ons kan dit ook so stel: Prediker het wel "geloof" maar mis die ",liefde" en tot 'n groot mate die ,hoop'. Hy val nic onder die goddeloses vir wie die mag van Jahwe ,verskrikking" is nie. As ons in Westerse woorde en in Grieks-Latynse taal wil spreek, kan ons so sê: God is predistinerend en sy weë het vir Prediker die kwaliteit van 'n ,fatum," maar tog nie 'n verskrikkende ,fatum" nie. Juis deur die predestinasie word die ,fatum" minder wetmatig en milder en moet dit met on t s a g (d.i. die inhoud van Godsvrees by Prediker) aanvaar word. Tog mis Prediker die lugtige blyheid van dié een wat Jahwe as die liefdevolle Verbondsgod ken. Alleen in $12^{13}$ lê Prediker meer nadruk op die „Deus Revelatus" (God geopenbaar deus Sy gebooie) as op die „Deus Absconditus". Daarom is daar in $12^{13}$ ook meer hoop, vertroue en vreugde, al is dit meer ingetoë as in Spreuke.

(b) Behalwe in $12^{13}$ beteken Godsvrees dus on ts a g, „Ehr-furcht" voor die verhewe God (51).

(c) Dan is daar ook sterk elemente van ooreenkoms met Spreuke bv. be s onne nheid (Pred. $5^{6}$ en Spr. $14^{16}$ ), d e e moed (Pred. $7^{18}$, Spr. $15^{33}, 22^{3}$ ens.), die gedagte van die loon van 'n kwalitatieflang lewe (Pred 812-13).

(1) Gemser, p. 90; Hertzberg, p. 185.

100) HertzBerG, p. 188. 


\section{SISTEMATIESE GEDEELTE}

\section{(a) IETS OOR DiE Metode.}

Daar is verskillende metodes waarop ons bogenoemde probleem kan aanpak en uitwerk. Sommige mag korter en minder vermoeiend wees, maar nie één is só leersaam en só noodsaaklik as die eksegetiese behandelingswyse nie. Veral in hierdie tyd van hoofkonjunktuur van die ,sistematiese teologie" is eksegese baie, baie noodsaaklik. Ons het ons in ons behandelingswyse veral hierdeur laat lei. Ons wou u u it - le i ( e x e ge $t$ i s e e r) langs alle steiltes en draaie en ons wou u by elke plek (teks) laat stilstaan om aan $u$ te wys hoe mooi die hele weg en landskap is, waarlangs ons met die gedagte geloop het. Nou wil ons graag dit wat ons gesien het, in 'n wyer raamwerk plaas.

\section{(b) Die Wyer samehange waARin ons ondersoek staAN.}

1. Spreuke, Job en Prediker sorteer onder die Literaturgattung wat bekendstaan as die Wysheidsliteratuur van die O.T. ${ }^{101}$.) Ons het telkens hierdie agtergrond sigbaar laat word wanneer dit nodig was vir die verstaan van enkele tekste. Vir die betere verstaan van die g e h e e 1 kan ons hier 'n kort tipiek gee van die raamwerk waarin ons materiaal staan, van die agtergrond waarteen dit duideliker gesien kan word: Die wysheidsleer is ' $n$ heersende geestesmag in die Israelitiese vroomheid, veral van later tyd. Die inhoud is praktiese lewenswysheid betreffende die sedelike wandel. Dit is tegnies 'n formulering en versameling van reëls van lewenskunde, om die enkeling se lewe tot 'n gelukkige en welgeslaagde te vorm. Dit het 'n kategeties-pedagogiese doel. Hoewel dit wetvrye vroomheid is, klink die onderhouding van gebooie tog telkens deur. Die karakter van die wysheidsleer is naïef-eudemonisties, a-histories, a-nasionaal en a-kulties. Die enkeling staan hierin sentraal. Dit is die religi e us e humanisme van Israel en is as sodanig universalisties gekleurd. Dit is in sy eskatologie veral tot hierdie lewe beperk. Die vergelding is die sentrale dogma van die Israelitiese wysheidsleer. Wysheid word baie keer i.v.m. die skeppingsmag van God gebring. Veral in die latere wysheidspsalme word die teodikêprobleem met skerpte te berde gebring. ${ }^{102}$

2. Ook het ons alreeds daarop gewys dat (aangesien die vrees-vandie-Here 'n verwoording is van 'n bepaalde en tog ryk-geskakeerde verhoudingswyse van die mens tot God en sy openbaring) dit vir die

101) Daar is ook nog ander dele v.d. O.T. wat hieronder sorteer nl. Amos $3^{3-8}$ $5^{3,10}, 6^{12} ;$ HOSEA $8^{7}, 10^{1,13 v} ;$ JES. $1^{3}, 2^{22}, 3^{10 \mathrm{~V}}, 10^{15}, 28^{23-28}, 32^{5-8} ;$ MICHA 24; JER. '1323, $17^{5-11}, 23^{28}, 31^{20}$; HAB. $2^{8}$; Es. $6^{44}$; Ps. 1, $19^{12}, 32^{8-11}, 34^{12-23}, 49,73,94^{8-38}$, $111,112,119,127$ en 128.

102) Vgl. oor hierdie tipiek: E. Sellin, Einleitung, 7A., p. 134-135 en Isr.jiid. Religionsgeschichte, p. 114v.v.; R. Kitres, Die Religion des Volkes Israel, 2A., p. 175v.; 1908 ; B. Gemser, Sprüche, p. 1-2, p. 6, p. 37, p. 55-57. 
betere verstaan van die Jahwevrees tog goed sal wees om na te gaan op welke bepaalde wyse God en mens tot openbaring kom in die Wysheidsliteratuur. Hierdie gedagte wil ons nou as wyer samehang vrugbaar maak as verstaansagtergrond van ons onderwerp in sy geheel: Ons het hier met 'n gekompliseerder saak- en gedagtekompleks te doen, as wat die bostaande eenvoudige uitspraak laat vermoed. Aan die een pool van hierdie verhoudingswyse staan God. Sy heiligheid, Sy mag in Sy werk in die heilsgeskiedenis, Sy mag in Sy Skeppingswerke én Sy „nabyheid”, Sy teenwoordigheid in Sy openbaring - in Teofanie, gebooie en ordeninge - is dié dinge wat ,vrees" wek. Aan die ander pool staan die mens. Die openbaring beskou die mens nie as 'n enkelvoudige ,syn" nie. In sy enkelheid of gemeenskap, in sy syn as spotter of as ellendige, geringe, arme en behoeftige, in sy deemoed of oormoed, in sy liefde, trou en vertroue en in sy "vrees" is die mens iemand van 'n besondere bepaaldheid en gekompliseerdheid in die lig van Gods Woord.

(a) Ons sal hier eers oor God spreek:

(i) Sy heiligheid is bepalend vir die vrees-van-die-Here. Indien ons God die objektiewe pool in die Godsvrees wil noem, kan ons sê dat Gods heiligheid die objektiewe ontologiese moment is in die vreesvan-die-Here-God. KöHıER ${ }^{103}$ ) sê: „Heilig gleich erhaben, überlegen und furchtbar." Die heiligheid skep distansie tussen God en wat-aan-Hom-behoort én die kreatuurlike dinge. HeMPEL ${ }^{104}$ ) bring ook die moment van die heiligheid i.v.m. die Godsvrees: „Die erste Gestalt des Abstandgefühls ist das Gefühl der b a nge n $\mathrm{Scheu}$, das mit jeder Berührung mit dem 'Heiligen' unertrennbar verknüpft ist." SelliN ${ }^{105}$ ) wys daarop dat Gods verhewendheid en heiligheid behalwe met die woorde eljōn, rām, gadōl ook met die woord nōrā (vreeslik) weergegee kan word. Heiligheid is afgesonderdheid en verhewendheid bo die kreatuurlike dinge. In die ouere geskrifte geld dit veral die natuurlike dinge; in die na-Jesajaanse tyd betrek dit sig veral op die etiese lewenssfeer - Gods oneindige sedelike reinheid is hier tegelyk Sy fisiese verhewenheid. Heiligheid is daar waar afstandsgevoel van die mens teenoor God uitkom. In die kultus-religie is God en die-wat-aan-Hom-behoort (volk, priesters) afgesonderd, heilig. In die wettiese godsdiensvorm is vrees en heiligheid ook nou verbonde. Die Heilige is in die O.T. die lewende God, Onderhouer, Skepper en Werker in die geskiedenis van Sy volk en ander volke. ${ }^{106}$ ) Hier in die O.T. en hier alleen maak die heiligheid die diepste kern van Gods wese uit. ${ }^{107}$ )

(ii) Maar die vrees-van-die-Here ontstaan en bestaan nie net voor hierdie ontologiese moment nie, maar ook uit die dinamiese moment wanneer die Heilige-van-Israel werk in die Heilsgeskiedenis. In die oudste

\footnotetext{
103) Theologie, 2A., 1936, p. 33-35 Ons spasiëring.

106) Hempel, p. 4 Ons spasiëring.

105) Theologie, p. 23-24.

108) Vgl. GeMser, Spriiche, p. 6, 23.

107) Oтто.
} 
oorkondes van die O.T. klink die lied deur $\left.{ }^{108}\right)$ : ,Jahwe is 'n Krygsman!” (Vgl. Ex. $15^{3}$ ). Jahwe stry egter teen Sy vyande wat tegelykertyd die vyande van Israel is. Dit ontlok jubeltone van Sy volk. HeMPeL ${ }^{109}$ ) stel dit as volg: Die mag van die Here tree v e $\mathrm{r}$ a l tevoorskyn in die oorlog bv. die segeryke inbraak van die "huis van Josef" in die kultuurland. In die ,kryg van Jahwe" met haar parole van wilde veglus en wraak beleef die mens Jahwe se vernietigende, verterende en dodende mag met vreugde en gejubel (Vgl. Ex. 15 ${ }^{21}$ ). Maar deur die hele O.T. klink hierdie lied met sy dubbele klank deur. So is dit bv. ook by die profete: Esegiël prys bv. die blinkgeslypte swaard van die Here ${ }^{110}$.) As die enkeling sy vertroue op die hulp van Jahwe wil vestig, gebruik hy soms 'n krygsbeeld (Jahwe se pyl en boog, Jahwe is 'n skild en pantser) ${ }^{111}$.) Ook in die eskatologie klink die kryg deur en slaan die benouende vrees skielik oor in blye gegjubel. Die vyande (teëstanders, ongeregtiges, trotsaards, haters, spotters het almal die ,"vyandige" klank van die oorspronklike vyand) vrees werklik; die hart wat Gods Woord in religieuse sin vrees, het vastheid, vertroue, ongestoorde rustige lewe en gejubel.

Jahwe is dus die heilige en geweldige alleenmagtige. Dit wek afstandsgevoel, vrees, bang-wees. Maar vir Sy volk, vir dié wat op Hom vertrou, is $\mathrm{Hy}$ die enigste helper in 'n wilde, vyandige wêreld. Die afstandsgevoel (nietigheid, stof, as, leed) word dryfveer vir verbondenheid, wete van die nabye hulp van God en selfs motief van verlossing. En tog gaan die „,oorspronklike" betekenis van die werklike vrees nooit verlore nie - die afstand is altyd dáár. Om hierdie hele gevoelskompleks in één uit te beeld, word die woord ,,vrees", vrees-van-die-Here, gebruik.

Wat ons hierbo histories gestel het, kan ons as struktuur só stel: Vrees beteken werklike vrees (bv. Ps. $27^{3}, 31^{14}, 56^{45}, 78^{53}$ ) selfs i.v.m. God (Ps. 33 $3^{8-10}, 114^{7}$; Job $9^{35}$ ). Maar hierdie woord oorskry sy ,,oorspronklike" grense en staan ,later" selfs sinoniem met batah = vertrou (Ps. $31^{20}, 38^{18}$ ) en dek die hele gevoelskaal van skrik, huiwering, ontsag, eerbied, afstandsgevoel, vertroue, liefde ${ }^{112}$ ) ) Tog raak die oorspronklike element van werklike vrees nooit op die agtergrond nie ${ }^{113}$.) Hierdie historiese verbondenheid van die begrip ,,vrees" laat dit vir ons ook duideliker word waarom dit so veelvuldig in die O.T. gebruik word om die Godsverhouding an te duie - dit is paslik om die Godsverhouding uit te druk, omdat dit wesenlik met die hele gang van die heilsgeskiedenis verbonde is, en daarin sentraal staan.

En alhoewel die aktuele geskiedenis in die Wysheidsliteratuur op die agtergrond tree, verloor hierdie historiese gegroeidheid van die begrip nooit sy werklike tweepolige waarde en betekenis nie. Die ou krygslied

\footnotetext{
108) Sellin, Einleitung, p. 20-23; A. Causse, Les plus vieux chants de la Bible.

109) HEMPEL, p. 33v.

$\left.{ }^{110}\right)$ Es. $21^{13}$. Vgl. ook Jer. $46^{10}, 47^{6}$; Jes. $27^{1}, 34^{6}$.

111) Job 6 $6^{4}$ Ps. $3^{4}, 24^{7 v}$., $91^{\text {iv }}, 119^{161}, 144^{\text {iv }}$.

112) Gemser, N.T.S.

113) KÖHLER, p. 36.
} 
met sy dubbele toonklank klink hier in die Wysheidsliteratuur weer en nogeens deur in die dubbelpolige sin van die begrip. Dit was veral Oтro wat daarop gewys het dat die religieuse vrees nooit eenledig vlugaanjagend is nie, maar dubbelpolêr. Dit is nl. samestoting van die mysterium tremendum em mysterium fascinans tot één eenheid. EIcHRODT ${ }^{114}$ ) meen dat die afstandsgevoel altyd dominant bly in die O.T., maar dat die middelpunt van die pendulum wat tussen hierdie twee pole swaai, die religieuse „Scheu" is. HEMPEL ${ }^{115}$ ) stel dit soos volg: Alle egte heiligheidsbelewenisse het beide die element van vrees en begeer in één. Die ark is ' $n$ gevaarlike voorwerp, maar bring tog seën mee. Die Sinai-teofanie is verskriklik en tog verwys later geslagte daarna as 'n groot moment, as 'n seën. Die oorspronklike psigologiese kompleks is werklike vrees. Dit splits in sy twee komponente op, nl. heil en onheil, wat egter altyd nou verbonde bly. Immanuel hou tegelyk vrees en lig-en-lewe in. Die profete beef voor die geweldigheid van Jahwe en tog is dit 'n saak van nie-kan-loskom-van-God, 'n genadegawe om Sy Woord te mag hoor en spreek. Jahwevrees is nie suiwer ,vrees" nie, maar is ook nie verlange na mistieke eenwording met God nie, dit is afstandsgevoel en verbondenheidsgevoel in één. Jahwe se heiligheid (syn) en werke (openbaring) bepaal en kwalifiseer hierdie tweeledige gevoelskompleks wat wesenlik één is.

(iii) Hoewel die aktuele geskiedenis in die Wysheidsliteratuur terugtree - terwyl die historiese gemodifiëerdheid van die begrip egter sy waarde en sin behou - is die vreeswekkendheid van Gods mag in sy skeppingswerke daarin tog nog helder sigbaar. By Job is die elemente van aktiwisme asook van die grootsheid en "Unheimlichteit" van die skepping meer teenwoordig; by Prediker tree die gedagte van die vaste en ewige wetmatigheid meer op die voorgrond ${ }^{116}$.) Die kleur en toon van die begrip is by elkeen effens anders - by Job meer ,,psigologies", by Prediker meer „pessimisties”, maar agter albei lê die Skeppingsmag van God.

(iv) Dan is die Godsvrees baie nou verwant met die teenwoordigheid van God in Sy openbaring - ,das Erschrecken (= Furcht) vor dem 'nahen' Gott" soos Hempel dit noem. Gods teenwoordigheid kan ,direk" wees soos in die Teofanie (vgl. Ex. $20^{20}$ ), soos by die Profete aan wie Gods Woord gebeur. Hierdie aspek tree veral in Job tevoorskyn. Hier in Job (soos bv. in Ex. 20 ${ }^{20}$ ) word weereens die oer-verwantskap van die werklike vrees en die Jahwevrees duidelik sigbaar. Maar nou kan die teenwoordigheid van God ook in die heilige handeling, in die kultus wees. Gods-v rees beteken hier behoedsa a m heid om God nie met 'n onbedagte woord gelofte of daad tegemoet te tree nie (Vgl. Pred. $\left.5^{6}\right)^{117}$.) En dan is die teenwoordigheid van God en Sy heilige norma-

114) Eichrodt, Theologie des A.T., III TI., 1939, p. Iv.v.

115) HeMPEL, p. 26-32.

116) Vgl. Pred. $3^{14}$ en Job $28^{28}$ en $37^{22-24}$.

117) Selin (bv. Einleitung, p. 134v.v.) is dus nie heeltemaal korrek as hy die W/ys. heidslit. a n $\mathbf{t} \mathbf{i}$-kulties noem nie. 
tiewe Wil veral in Sy Woord. Sy Wil en Woord is in die Wysheidsliteratuur veral die Gebod. En alhoewel die Gebod meer vas en geordend is as die profetiese Woord wat aan die Profete $\mathrm{ge} \mathrm{beur}$, is dit nie minder aktueel nie, want dit deurdring die hele lewe en alle lewensgebiede, volgens die Wysheidsliteratuur. Hoewel dit minder ,akt-haft" is, is dit nie minder ,akt-uell" nie. Om gedurig op Sy gebooie ag te gee, daarmee in elke lewensmoment te reken, dit is Jahwevrees. Die etiekdeurdrongenheid van die Wysheidsliteratuur (óók van Job, bv. jsjr,tm drk ens.), die verankerdheid van die hele lewe en alle lewensgebiede aan God en Sy heilige Wil, spruit uit die ,vrees" vir die teenwoordigheid van God in Sy Gebod. Dit is dan daarom geen wonder dat Jahwevrees soveel voorkom in die Wysheidsliteratuur nie, geen wonder dat Jahwevrees daarin so eng met die gebod saamgekoppel word nie.

(b) Maar behalwe hierdie viervoudige koppeling van die Godsvrees aan die Wese, Werke en Woord van God, is daar nog die ander pool, nl. die spesifieke wyse waarop die mens sigbaar word in die Wysheidsliteratuur van die O.T. HemPeL ${ }^{118}$ ) sê dat die Wysheidsliteratuur dié vorm is wat ,,aufs stärkste das Leben gestaltet und Beziehungen zwischen Jahwe und dem Einzelnen in sich schliesst”. Hy meen ${ }^{119}$ ) dat die „Faszinöse" in die gebede van die enkelinge die oorwegende element is. Die koms van God is lewe en heil. MeInhold ${ }^{120}$ ) bevestig ook dat dit in die Wysheidsliteratuur oor die enkeling gaan. Dan sê hy verder: „Furcht, nicht Liebe ist sein Ausdrück für Religion, für das Verhältuis des Einzelnen zu Gott". GeMSER ${ }^{121}$ ) wys egter daarop dat die uitdrukking Jahwevrees parallel staan ,mit Demut, 'Liebe und Treue' und bezeichnet ein Vertrauensverhältnis," HICHRODT ${ }^{122}$ ) wys daarop dat die humanisme en individualisme in die O.T. veral in later tyd (hoewel dit altyd aanwesig was) sterk deurbreek. Hierdie individualisme bring veral die sterk wilselement in die godsdiens in, maak die godsdiens en lewe etiekdeurdronge (soos ons gesien het in die Wysheidsliteratuur). Dan waarborg dit ook die blywende afstandsgevoel tussen God en mensl Vir die individu is God „furchtbar erhaben”. Dit is hierdie afstandsgevoel wat ook 'n wesenlike element is in die Jahwevrees. Dan bring hierdie individualisme mee dat "Vrees" (naas liefde en geloof) 'n grondvorm is van die persoonlik-individuele Godsverhouding.

(c) Ons het ook gesien dat die Wysheidsliteratuur in sy huidige vorm 'n latere fase en vorm van die Israelitiese vroomheid is, alhoewel die wortels daarvan na vroeër jare teruggaan. Ook die begrip vreesvan-die-Here wat in die Wysheidsliteratuur so veelvuldig oopblom, se wortels groei uit 'n veel vroeër grond en word gevoed deur ouer bronne uit die O.T.-se Godsdiens. Ons wil hier dieper in die tyd teruggrawe sodat

\footnotetext{
118) HeMPEL, p. 233.

119) Idem, p. 30.

120) Meinholdt, p. 86 en 126.

121) Gemser, Sprüche, p. 21v.

122) EICHRODT, Theologie, III. TI. p. 1-18.
} 
die hele struktuur vir ons helderder kan word, veral in sy huidige samehang. Ludwig KöHLER ${ }^{123}$ ) sê dat die woord „Heilig" oorspronklik beteken het: iets (bv. volk) is afgesonder vir Jahwe. Niks moet deur hulle gedoen word wat God mishaag nie. Later betrek die ,heiligheid” sig op God. Dit bring die vreeslikheid van God én die kleinheid van die mens (bv. van Jesaja) na vore. Verder ${ }^{123}$ ) laat KöHLER sien dat hierdie heilige God egter vergeef; vreeslike dade met Israel doen. Hulle moet daarom Sy wil naspeur. Dit bring die elemente van die gebods-onderhouding en die welbewuste behoedsaamheid in die Godsvrees. In die deuteronomiese tyd word hierdie behoedsaamheid tot gaan-op-die-regte-weg, Sy-wil-doen = Sy-gebooie-bewaar $=$ Hom vertrou en liefhê.

Gods dade is dus vreeslik, verskrik die hele wêreld; maar Hy doen dit ten gunste van Israel. Hy sal dit ook altyd doen, maar dan verwag Hy ook 'n steekhoudende d.w.s. duratief-behoedsame houding van Israel. Hierdie houding word uitgedruk met die begrip: Vrees-van-die-Here $=$ gehoorsaamheid. So is die begrip vrees verinnerlik tot duratiewe, vertroulike vrees-van-die-Here wat teenoor die bangwees vir die skielike ongekende mag van die oomblik staan. Wat in die N.T. gehoorsaamheid heet, is in die O.T. Godsvrees. ${ }^{125}$ )

By EICHRODT ${ }^{128}$ ) het ons alreeds gesien dat hy die Jahwevrees (=Godsvrees) sien as een van die grondelemente van die persoonlike Godsverhouding. Hierin is die afstandsgevaoel dominant, maar só dat dit nie hier gaan om "Knechtseligkeit" nie, maar veeleer as 'n beweging tussen die twee pole van skrik én vertroue-en-liefde. Heiligheid bring vrees mee bv. by die profete. Die eiendomlike in die O.T. ontstaan daardeur dat daar geen magie is nie, en die mens die Heilige-van-Israel dus nie kan dwing nie, terwyl alle demone weg is, en God die enigste is wat heil én onheil (weer die dubbelpolarisme) as beslissing bring ${ }^{127}$ ). Die grondvorm waarin hierdie verhouding tot openbaring kom, is die verbondsluiting: Hoewel God die verskriklike is, is $\mathrm{Hy}$ tog trou aan Sy verbond. En so tree die skrik vir die Numineuse terug agter die eerbiedvolle „Scheu” bv. by die eenlinge Abraham en Dawid. Maar dan tree daar die element van verpligting op teenoor die verbondswil van God. Sy wil werk in die heilsgeskiedenis en werk deur in alle lewensgebiede. God is die grond vir die agting vir die lewensnorme. En so tree die skrikgevoel terug agter die altyd-teenwoordige goddelike verordeninge. Hierdie laasgenoemde is die positief-rasionele element in die Godsvrees: Namate die wil van God duideliker deurdring in alle lewensgebiede in, kom daar meer rustige vertroue. Gods vreeslike mag bly altyd egter die waarborg van hierdie vertroue. Agter die statiese, duratiewe elemente lê altyd nog die dinamiese element van verskriklike mag en skielike skrik.

123) KöhlER, Theologie, p. 33-35.

124) Idem, p. 35-38.

125) Idem. p. 94.

126) EICHRODT, t.a.p.

127) Gemser, N.T.S., p. 146v.v. 
HeMPEL ${ }^{128}$ ) meen dat „vrees" die oorspronklike taboe-gevoel vir heilige dinge en mense is. Hierdie ,skrik"-gevoel (maar dan ook verbonde met jubeling en vertroue) kom veral uit in die teofanie en oorlogsnabyheid van Jahwe. Maar nou vertrou Israel op Hom wat só verskyn en werk. Die Profete is bv. gegrepe deur die verskriklike geweld van Jahwe, maar tog bring Hy seën en heil mee in Sy spreke. So oorskry die woord „vrees" sy oorspronklike inhoudsgrense sodat Godsvrees = Religie word, en Godvresend = vroom. Dit word tot daad in die kultus en tot lewe in die etiek. Negatief is dit om die bose te vermy; positief om Sy gebooie te bewaar; die gevolg is Sy seëninge en die vertroue op Sy seënende krag. Ook die eskatologie laat beide die skielike skrik en onheil én die kwalitatief-rustig en geslaagde lang lewe en heil sigbaar word. In die kultus is die Numen Praesens vreugdevol. In die Wysheidsliteratuur is die „Vrees" meer rasioneel, eties-persoonlik en juis daardeur is die element van die vertroue so sterk.

LORENZ DürRR ${ }^{129}$ ) laat sien dat die O.T. veral in later tyd één term ken om die vroomheids- en opvoedingsideaal saam te vat, nl. Jahwevrees. Die opvoeding behels:

(i) die leer van die heilsgeskiedenis en die sigbaarmaking van die wil van God wat daarin werk. Die lang rye helde en heldedade boesem vertroue in. Tweedens omvat die opvoeding

(ii) die dosering van die tôrâ as inhoud van die genadeverbond, sodat dit goed mag gaan met hulle wat dit onderhou. Eerbied-hê en die maat-hou is hoofmomente in die Wysheids: eratuur. Soms kan Jahwevrees skrikwekkend wees, maar waar dit i.v.m. die opvoeding staan, is dit tere, nougesette "Scheu", behoedsaamheid, tere toeverlaat op Hom, Sy gebooie onderhou met die uitingsvorme van 'n rein sedelike lewe en selftug teen selfsug. Die samevattende terminus hiervoor is: Jahwevrees.

Dit is teen dié agtergrond van wyer samehange waaruit die begrip vrees-van-die-Here groei en waarin dit staan, dat ons dit duideliker kan begryp en verstaan. Ook hier - maar dan in ander en wyer verbande as die eksegetiese samehang - word die wesenlike elemente daarvan sigbaar. - (a) So sien ons ook hier die struktuur dat vrees = ,observance” $=$ religio (v.D. LEEw). In hierdie struktuur het die karakter van skielike skrik plek gemaak vir die duratiewe element. Hierdie skielike skrik is nog as agtergrond en teenpool daar: Die goddeloses sal nog hierdie skielike skrik ervaar in die abrupte einde. Die duratiewe element word veral sigbaar as ' $n$ kwalitatief-lang en rustige lewe selfs in en teenoor 'n vyandige wêreld. Dit is die versadigde rustigheid teenoor die skielike skrik van nagtelike onheil van-buite-af. Die vertroue op Hom is 'n sterk sekerheid, is rus, is 'n vesting, toevlug en waarborg.

(b) Omdat hier, met die vrees-van-die-Here, aan die netlyne van die diepste bestaanslae van ons menswees getrek word (ons menswees wat

128) HEMPEL, p. 4-33.

120) DürR, Das Erziehungswesen, p. 123v. 
wat hier gesien word as syn-voor-God en tegelykertyd as syn-in-diewêreld), is dit dus geen wonder dat die vrees-van-die-Here ook ons prakties-eties-eksistensiële lewe soos 'n suurdeeg deurtrek nie. Jahwevrees is die erkenning daarvan dat die hele lewe veranker is aan die wil en gebooie van God. Negatief is dit die afwysing van eie-willigheid, eiewysheid en self-vertroue. Die Jahwevresende is opreg van weg, $t m d r k$, jsjr. Sy lewe word uit die vlak van alledaagsheid uitgelis en leef in die sfeer van daaglikse (= duratiewe) vertroue op Hom; sy lewe is lewenskuns.

(c) Wanneer die mens staan voor die geweldige skeppingsdinge van God, dan tree die element van afstandsgevoel weer tevoorskyn en kan ons Jahwevrees vertaal met eerbied, „Ehr-furcht”. By Prediker kry ons veral ook die „ontsag” vir die verhewe God.

\section{(d) Die „Geskiedenis" van die begrip "Jahwevrees" in Spreuke, Job en Prediker.}

In die „Inleiding" het ons die betekenis en waarde van die ,,geskiedenis-van-'n-begrip" bepaal $\mathrm{nl}$. dat dit die historiese agtergrond is waarteen en waaruit 'n woord gespreek word en wat aan die woord 'n besondere kleur-klank gee. Hierdie sfeer en situasie se verstaan sal dien tot'n betere begryp. Aangesien die bepaling van die historese agtergrond altyd relatief sal wees, moet ons versigtig wees om nie op grond daarvan teologiese konklusies te trek nie. Vir die bet e r e versta a n van die begrip is hierdie weg egter vrugbaar en sal ons die tipiese trekke van die begrip in ' $n$ bepaalde afdeling helderder probeer sien teen die relatief-bepaalbare historiese agtergrond waarin hierdie afdeling staan en waaruit dit groei:

(a) $\mathrm{S} \mathrm{p} \mathrm{r} \mathrm{e} \mathrm{u} \mathrm{k} \mathrm{e} 10^{1}-22^{16}$ : Die vrees-van-die-Here het in hierdie afdeling (wat histories ook die oudste is) meestal die kwaliteit van Godsvrug, vroomheid, ,piety", "Religion”. Dit is as sodanig ook sterk eties gekleurd soos veral blyk uit die sterk aksentuering van die 1 o o n g ed a g t e in hierdie afdeling. As ons hierdie afdeling sien teen die wyer agtergrond van die O.T.-se geskiedenis, weet ons dat die begrip alreeds ' $n$ lang historiese loop deurgemaak het, en dat die loongedagte alreeds beslag gekry het deur die gedurige ervaring van die Goddelike weldade. Die loon word hier veral as weldaad en nie soseer as straf gesien. Daar is ' $n$ sekere rustigheid in sfeer en in die vereenselwiging van die Jahwevrees met Godsvrug en vroomheid. Die element van die ,tremendum" tree hier op die agtergrond deur die voorspoedige historiese verloop én deur eie ervaring van die goeie gawes van God. Dit (maar ook ander gronde) laat ons vermoed en begryp dat hierdie spreuke heelwaarskynlik stam uit die bloeitydperk van die koningskap van Israel. Daar is onmiskenbaar vreugde in die bestaande verhoudinge ${ }^{130}$ ), ook in die Godsverhouding. Die byna-landelike rustigheid vind ons in alle ver-

${ }^{130}$ ) Vgl. GeMSER, T.U., p. 22. 
houdinge weerspieël: Jahwevrees is rustige Godsvrug, is vroomheid; die ,tremendum"-gedagte is op die agtergrond en uit die ervaring van die goeie uit Gods hand, spruit die loongedagte.

(b) Spreuke 2217-24: Die tipiese toon en trek in hierdie afdeling is dat Jahwevrees parallel gestel word met $\mathrm{G}$ od s ve $\mathrm{r} t \mathrm{r}$ o u e . Hierdie spreuke stam heelwaarskynlik uit die $7 \mathrm{de}$ eeu, uit die deuteronomiese tyd. In hierdie tyd is daar skommelinge in die volkerewerreld, is daar nie meer dieselfde sfeer van rustigheid as in Hoofst. 10-22 se agtergrond nie. In hierdie tyd van onvastigheid word daar gemaan om die hoop op Jahwe te vestig vir sekerheid en vastigheid vir die toekems, word daar aangespoor om op Jahwe te vertrou en die lewe aan Hom te veranker (Vgl. Spr. 2317). Teen revolusie word gemaan en gehoorsaamheid en vertroue met die oog op toekomsveiligheid word aanbeveel. Dat die religieuse lewe nie meer so kragtig is nie, blyk uit die waarskuwing teen die benyding van die skynbare voorspoed van die sondaars. En tog; juis dat daar vermaan en aangespoor word, wys op 'n nuwe herlewing van die religieuse lewe in hierdie tyd. Die grond van hierdie vertroue en sekerheid word weliswaar nie meer in die huidige ervaring van die goeie gevind nie, maar veeleer in die geskiedenis; maar die huidige toestand bring juis mee dat die mens Jahwe sal soek, op Hom sal vertrou, met angstige huiwering op Hom sal vertrou.

(c) Spreuke 1-9: Tipies van hierdie groep spreuke is dat Jahwevrees met wy sheid en kennis gelykgestel word. Hierdie spreuke stam uit ' $n$ later periode van die geskiedenis en godsdiensgeskiedenis van Israel en weerspieël 'n min-of-meer stedelike agtergrond. Ook hierdie afdeling betrek sig op die etiese gebied van die lewe, maar dan tog nie die rustige praktiese lewe van Hoofst. 10-22 nie. Hierdie deel is meer filosofies en onpersoonlik, betrek sig meer op die we t -as-wilvan-God as op die daad-werklike ervaring uit die hand van God óf op die heilsgeskiedenis waarin die gelowige die weldade en redding van Jahwe sien. Wat in Hoofst. 10-22 daad-werklike lewe was, is hier verinnerlik tot pedagogiese lewens-filosofie. In hierdie afdeling is die vrees-van-die Here meer onpersoonlik, minder intiem, meer filosofies en „,rasioneel”berekend soos die geskiedsfase van hierdie tyd ook is.

(d) J o b : Die boek Job het aan ons ondersoek verskyn as 'n profeties-existensiële protes teen een van die grondstellings van die oorgelewerde wysheid, nl. 'n protes teen die geloof aan die onfeilbaar, byna-meganies op aarde sig voltrekkende goddelike vergelding. Dit is as sodanig 'n protes teen die hele oorgelewerde "Wysheid" wat effens té rasioneel-berekend, filosofies, staties en onpersoonlik, té on-d a a dwerklik geword het. Hierdie „protes" is nie bloot protes nie, maar is gebore uit innerlike eksistensiële sielsnood van één wat weer soos Jakob voor ,die-aangesig-van-God" worstel met God. In Job kom die lewende, persoonlike God weer tot openbaring teenoor die onpersoonlike, filosofiese God. Jahwevrees word weer die verhouding tot hierdie lewende, 
numineuse God. Daarom tree die element van die „tremendum" weer op die voorgrond soos dit in die ou dae was en klink die klanke van die vroeëre spreuke ook weer deur.

(e) Prediker is die laaste produk van die O.T.-se Wysheidsliteratuur. Verskillende klanke en strominge wat in vroeër tye van die O.T. vreemd was, word hier hoorbaar en sigbaar. Ons laat die vraag onbeslis of hierdie vreemde nuwe dinge van buite af gekom het, óf van binne Israel uit gegroei het. Ons konstateer alleen dat teen hierdie agtergrond van nuwe, vroeër vreemde filosofie die Prediker tog nog gelowig is, met God en Sy wet bekend is. Tussen Spreuke 1-9 en Prediker is 'n bepaalde verband. Prediker is alleen meer ab-strak, meer konsekwent. Hy lê meer nadruk op die verhewenheid van God, op die Deus absconditus, en die mens se verhouding tot hierdie God (d.w.s. sy Godsvrees) word on ts a g, pi ë te i t, eerbiedige erkenning van die mes se kreatuurlikheid, genoem. Miskien is hierdie distansiële element 'n veraf naklank van die donker dromme en donderweer wat in Job geklink het. Die verskil is egter dat dit hier 'n on pers o onlike distansiële element is - wat in Job daadwerklik en persoonlik beleef is, word hier alleen maar met gelate woorde gesê. En tog is albei hierdie boeke in die kanon; tog is dit goed dat ons na die verskillende klanke van altwee goed sal luister; ewe goed sal luister.

Florida, Maart 1951.

B. J. ENgelbrecht. 